\title{
Yöneticilerin Yetenek Yönetimi Yetkinliklerinin İşgörenlerin İşten Ayrılma Niyeti ile İlişkisinde Duygusal Bağlılık, Çalışmaya Tutkunluk ve İş Tatmininin Aracılık Rolü: Bankacılık Sektörü İşgörenleri Üzerine Bir Araștırma
}

\author{
(The Mediating Roles of Affective Commitment, Work Engagement and Job Satisfaction \\ on the Relationship Between Managers' Talent Management Competencies and \\ Employees' Intention to Quit: A Research on Banking Sector Employees)
}

\author{
Hüseyin $\mathrm{BOZ}$ i a \\ a Akdeniz Üniversitesi, Antalya, Türkiye.hboz@akdeniz.edu.tr
}

\section{MAKALE BİLGİsi \\ Anahtar Kelimeler: \\ Yetenek Yönetimi Çalışmaya Tutkunluk Duygusal Bağlılık \\ İş Tatmini \\ İşten Ayrılma Niyeti}

Gönderilme Tarihi 3 Nisan 2021

Revizyon Tarihi 25 Kasım 2021

Kabul Tarihi 10 Aralık 2021

Makale Kategorisi: Araştırma Makalesi

\section{ÖZET}

Amaç - Çalışmanın temel amacı, yöneticilerin sahip olduğu yetenek yönetimi yetkinliklerinin, işgörenlerin işten ayrılma niyeti üzerindeki etkisini ve bu ilişkide duygusal bağlılık, çalışmaya tutkunluk ve iş tatmini değişkenlerinin aracı rol üstlenip üstlenmediklerini araştırmaktır.

Yöntem - Araştırmanın verileri Antalya'da faaliyet gösteren 5 farklı bankanın 376 işgöreninden anket tekniği kullanılarak toplanmıştır. Araştırmada algılanan yönetici yetenek yönetimi yetkinliklerinin ölçülmesinde Oehley (2007) tarafından geliştirilmiş olan Yetenek Yönetimi Yetkinlikleri Ölçeği'nden yararlanılmıştır. İşgörenlerin çalışmaya tutkunluk düzeylerini belirlemek amacıyla Schaufeli vd. (2002) tarafından geliştirilen Utrecht Çalışmaya Tutkunluk Ölçeği kullanılmıştır. İşgörenlerin duygusal bağlılıklarını ölçmek için Allen ve Meyer (1990) tarafından geliştirilen ve örgütsel bağlılık ölçeğinin parçası olan duygusal bağlılık ölçeği kullanılmıştır. İşgörenlerin iş tatminini ölçmeye dönük Weiss vd. (1967) tarafından geliştirilen Minnesota İş Tatmini Ölçeği kullanılmıştır. İşgörenin işten ayrılma niyetini ölçmeye dönük Rusbult vd.'nin (1988) işten ayrılma niyeti ölçeğinden yararlanılmıştır. Araştırmanın hipotezleri yapısal eşitlik modellemesinden yararlanılarak test edilmiştir.

Bulgular - Araştırmada dört hipotez test edilmiştir. Yöneticilerin yetenek yönetimi yetkinliklerinin işgörenlerin işten ayrılma niyetine üzerinde doğrudan negatif etkisinin olduğunu belirten Hipotez 1 kabul edilmiştir. Yöneticilerin yetenek yönetimi yetkinlikleri ile işgörenlerin işten ayrılma niyeti arasında duygusal bağlılığın aracılık rolüne işaret eden Hipotez 2 de kabul edilmiştir. Yöneticilerin yetenek yönetimi yetkinlikleri ile işgörenlerin işten ayrılma niyeti arasında çalışmaya tutkunluğun aracilık rolüne işaret eden Hipotez 3 desteklenmemiştir. Yöneticilerin yetenek yönetimi yetkinlikleri ile işgörenlerin işten ayrılma niyeti arasında iş tatmininin aracılık rolüne işaret eden Hipotez 4 desteklenmiştir.

Tartışma -Alanyazınla tutarlı biçimde, yöneticilerin yetenek yönetimi yetkinliklerinin, işgörenlerin işten ayrılma niyeti üzerinde doğrudan negatif etkisinin olduğu görülmektedir. Bunun yanında, yine alanyazınla tutarlı biçimde işgörenlerin duygusal bağlllıklarının ve iş tatminlerinin yöneticilerin yetenek yönetimi yetkinlikleri ile kendilerinin işten ayrılma niyetleri arasında aracı rol oynadığı dikkat çekmektedir. Yöneticilerinin yetenek yönetimi yetkinliklerinin yüksek olduğu algısılyla, örgüte duygusal olarak bağlılıkları ve iş tatmini düzeyleri artan yetenekli işgörenler bunun etkisiyle işletmeden ayrılma niyetinden uzaklaşmaktadır. Diğer yandan, işgörenlerin çalışmaya tutkunluğunun yöneticilerin yetenek yönetimi yetkinlikleri ile işgörenlerin işten ayrılma niyeti arasında aracılık rolünün olmadığı görülmektedir. Bu durumda, çalışmaya tutkunluğun aracilık etkisine ilişkin elde edilen sonucun alanyazınla örtüşmediği söylenebilir. Bu sonucun test edilen ana model bağlamında, çok sayıda değişkenin ilişkisinin aynı anda ele alınmasından ileri gelebileceği düşünülmektedir.

\footnotetext{
${ }^{1}$ Bu çalışma Prof. Dr. Nilgün Anafarta danışmanlığında, Hüseyin Boz tarafından hazırlanan “Yöneticilerin Yetenek Yönetimi Yetkinliklerinin İşten Ayrılma Niyeti ile İlişkisinde Duygusal Bağlılık, Çalışmaya Tutkunluk ve İş Tatmininin Aracılık Etkisi: Bankacılık Sektöründe Bir Araştırma" başlıklı doktora tez çalışmasından üretilmiştir.

Önerilen Atıf/Suggested Citation

Boz, H. (2021). Yöneticilerin Yetenek Yönetimi Yetkinliklerinin İşgörenlerin İşten Ayrılma Niyeti ile İlişkisinde Duygusal Bağlılık, Çalışmaya Tutkunluk ve İş Tatmininin Aracılık Rolü: Bankacılık Sektörü İşgörenleri Üzerine Bir Araştırma, İşletme Araştırmaları Dergisi, $13(4), 3236-3264$.
} 


\section{ARTICLE INFO}

\section{Keywords:}

Talent Management Work Engagement Affective Commitment Job Satisfaction Intention to Quit

Received 3 April 2021 Revised 25 November 2021 Accepted 10 December 2021

Article Classification: Research Article

\section{ABSTRACT}

Purpose -The main purpose of the study is to investigate the effect of the managers' talent management competencies on the employees' intention to quit and whether the variables of affective commitment, work engagement and job satisfaction undertake a mediating role in this relationship.

Design/methodology/approach - The data of the research were collected from 376 employees of 5 different banks operating in Antalya using the survey technique. The Talent Management Competencies Scale developed by Oehley (2007) was used to measure the perceived talent management competencies of managers in the study. The Utrecht Work Engagement Scale developed by Schaufeli et al. (2002) was used to determine the level of work engagement of employees. Affective commitment scale, which was developed by Allen and Meyer (1990) and is a part of the organizational commitment scale, was used to measure the affective commitment of employees. Minnesota Job Satisfaction Scale developed by Weiss et al. (1967) was used to measure employees' job satisfaction. Rusbult et al .'s (1988) intention to quit scale was used to measure the employees' intention to quit. The hypotheses of the research have been tested using structural equation modeling.

Findings - Four hypotheses were tested in the study. Hypothesis 1 was accepted, which states that the managers' talent management competencies have a direct negative effect on the employees' intention to quit. Hypothesis 2, which indicates the mediating role of affective commitment between managers' talent management competencies and employees' intention to quit, was also accepted. Hypothesis 3, which indicates the mediating role of work engagement between managers' talent management competencies and employees' intention to quit, was not supported. Hypothesis 4, which indicates the mediating role of job satisfaction between managers' talent management competencies and employees' intention to quit, was supported.

Discussion - Consistent with the literature, it is seen that the mamagers' talent management competencies have a direct negative effect on employees' intention to quit. In addition, again consistent with the literature, it is noteworthy that the affective commitment and job satisfaction of the employees play a mediating role between the managers' talent management competencies and empleyees' intention to quit. With the perception that their managers have high talent management competencies, talented employees whose affective commitment to the organization and their job satisfaction levels increase, move away from the intention of quit of the business. On the other hand, it is observed that the employees' work engagement does not have a mediating role between managers' talent management competencies and employees' intention to quit. In this case, it can be said that the result obtained regarding the mediating effect of work engagement does not correspond to the literature. It is thought that this result may arise from considering the relationship of many variables at the same time in the context of the main model tested.

\section{Giriş}

Baş döndürücü bir hızla gelişen ve ilerleyen teknolojinin etkisiyle işletmelerin rekabette ayakta kalması gün geçtikçe daha zor hale gelmektedir. Özellikle 1980'li yıllardan itibaren dünyada ve ülkemizde küreselleşmenin ve bilgi ekonomisinin artan etkisiyle işletmeler kendilerini yoğun bir rekabetin içinde bulmuşlardır (Yılmaz, 2009; Kevük, 2006). Gün geçtikçe daha dinamik bir görünüm kazanan rekabet anlayışı, hangi sektörde faaliyet gösterdiğine bakılmaksızın işletmelerin çevrelerinde yaşanan değişimlere kayıtsız kalmamasını ve bu değişimlere uygun yönetsel kararlar alabilmesini gerekli kılmaktadır. Bu süreçte işletmeler arasında her alanda baş gösteren rekabetçi anlayış, yüksek potansiyele sahip ve yüksek performans göstereceğine inanılan yetenekli işgörenlerin cezbedilerek işletmeye kazandırılması, yetiştirilip geliştirilmesi ve elde tutulması konularında da kendini göstermeye başlamıştır.

Özellikle McKinsey\&Company araştırmacılarının 1997 yılında yaptığı araştırmayla (Collings ve Mellahi, 2009; Michaels vd., 2001) gündemi işgal etmeye başlayan 'yetenek savaşı' olgusu işletmelerin dikkatlerini bütünüyle yetenekli işgörenlere yöneltmesinde etkili olmuştur. McKinsey\&Company araştırmacılarının sözü edilen bu çalışmasının 'yetenek yönetimi' kavramının da ortaya çıkmasının yolunu açtığ 1 söylenebilir. Hakkında özellikle son dönemlerde çok sayıda çalışma yapılmasına karşın, tanımlanması konusunda tam bir uzlaşı sağlanamadığı görülen yetenek yönetiminin ana hatlarıyla yetenekli olarak değerlendirilen işgörenlerin cezbedilmesi, geliştirilmesi ve elde tutulmasına odaklandığını söylemek yerindedir. Birçok ülkede işsizlik oranlarının ciddi düzeyde olmasına karşın, işleri yapacak olan gerekli donanıma sahip yetenekli işgören kıtlığının yaşanması yetenek yönetimini işletme stratejileri içinde önemli bir konuma getirmiştir. Yetenek yönetimi konusunda her koşulda geçerli olan, her işletme için aynı şekilde ele alınabilecek yetenek yönetimi süreçlerinin olduğunu söylemek doğru olmayacaktır. Yani, her işletme yetenekli işgörenlerine dönük farklı yetenek yönetimi stratejileri ve süreçleri izleyebilmektedir. 
Yetenek yönetiminin gerek akademik camiada, gerekse uygulamacılar arasında yoğun şekilde tartışılmaya ve irdelenmeye başlanmasıyla birlikte, farklı sektörlerde faaliyette bulunan birçok işletme örgütsel ve bireysel çıktılar üzerinde olumlu sonuçlar doğuracağı beklentisiyle yetenek yönetimi uygulamalarına yönelmişlerdir. Ancak gerek yerli gerekse yabancı yetenek yönetimi alanyazını incelendiğinde, yetenek yönetiminden farklı yönleriyle bahseden çok sayıda çalışma olmasına karşın, yetenek yönetiminin başka kavramlarla olan ilişkisine dikkat çeken çalışmaların ancak son zamanlarda artma eğilimi gösterdiği görülmektedir. Yapılan bu araştırma, işletmelerde yetenek yönetimi uygulamalarının doğurması olası bazı sonuçları belirli bir model çerçevesinde irdelemesi açısından değerlidir. Çalışmada yöneticilerin sahip olduğu yetenek yönetimi yetkinliklerinin işgörenlerin işten ayrılma niyeti üzerinde doğrudan etkisinin olup olmadığı, bunun yanında işgörenlerin duygusal bağlılıklarının, iş tatminlerinin ve çalışmaya tutkunluklarının bu ilişkide aracı rol üstlenip üstlenmedikleri araştırılmaktadır. Oehley'in (2007) yöneticilerin yetenek yönetimi yetkinlikleri ile işgörenlerin işten ayrılma niyeti ilişkisini, duygusal bağlılık ve iş tatmininin aracılık etkisiyle birlikte ele aldığı modele, alanyazına dayalı olarak çalışmaya tutkunluğun aracılık etkisinin de dâhil edildiği bu çalışma, yetenek yönetimi uygulamalarının bütüncül bir model dâhilinde etkilerini ortaya koyması açısından önem arz etmektedir. Araştırma Türkiye'de yetenek yönetimi uygulamalarının en yoğun uygulandığı sektörler arasında yer alan bankacılık sektöründe çalışan yetenekli işgörenler bağlamında ele alınmıştır.

\section{Kuramsal Çerçeve ve Araştırma Hipotezleri}

\section{Yetenek Yönetimi ve Yönetici Yetenek Yönetimi Yetkinlikleri}

Günümüzde akademik dünyada ve uygulamacılar arasında sıklıkla kullanılan yetenek yönetimi kavramı 1990 'lı yılların sonunda ortaya çıkmıştır. Kavramın popüler hale gelmesi ise, McKinsey\&Company danışmanlık şirketi araştırmacılarının 1997 yılında yaptıkları çalışma sonrasında olmuştur (Michaels vd., 2001). Yetenek yönetimi alanyazını incelendiğinde, kavrama ilişkin ortak bir tanımlamaya gidilmediği göze çarpmaktadır. Yetenek yönetimine dair farklı bakış açıları birbirinden farklı tanımları ortaya çıkarmaktadır (Lewis ve Heckman, 2006). Yetenek yönetimi doğru zamanda, doğru işe, doğru kişiyi almayı amaçlayan uzun soluklu uygulamaları kapsayan uygulamacı temelli olarak ortaya çıkmış bir terimdir. Yetenek yönetimi işgücü planlamasını, yedekleme planlamasını, işgörenlerin gelişimini ve kariyer yönetimini içerir (Cappelli ve Keller, 2014: 306). "Yetenek yönetimi, yüksek potansiyeli ile örgüt için özel değeri olan işgörenlerin sistematik biçimde cezbedilmesi, tanımlanması, geliştirilmesi, çalışmaya tutkun hale getirilmesi/elde tutulması ve işletme içinde bunların yayılmasıdır." (CIPD, 2007: 3). Bu tanım yetenek yönetiminin yeteneğin cezbedilmesinden, yeteneğin elde tutulmasına kadar uzanan farklı aşamaları içerdiğinin altını çizmektedir. Atlı (2012), yetenek yönetiminin insan kaynakları yönetimi ile aynı olduğunu ifade eden görüşlerin olmasına karşın, gerek iş dünyasındaki uygulamalar gerekse akademik yazındaki ilgiye bakarak yetenek yönetiminin yeni bir aşamaya işaret ettiğini vurgulamaktadır.

Cheese vd.'ne (2008) göre, insan kaynakları uygulamaları üzerine kurulu, fakat sadece insan kaynaklarının sorumluluğunda olmayan yetenek yönetimi yaklaşımının benimsenmesi işletmedeki tüm işgörenleri içine alır. Avrupa'da insan kaynaklarının geleceğini ele alan bir araştırmada (Economist Intelligence Unit, 2006: 3), araştırmaya dahil olan şirketlerin CEO'ları yetenek yönetiminin sadece işletmelerin insan kaynakları bölümlerine bırakılamayacak kadar önemli bir konu olduğuna dikkat çekmişlerdir (Collings vd., 2009: 6). Yetenek yönetimi süreçleri tasarlanırken ve yetenek yönetimi uygulamaları gerçekleştirilirken, işgörenlere yetenek odaklı bakış açısının benimsenmesinde işletme içerisinde başta tepe yönetiminin olmak üzere, insan kaynakları bölümünün ve ortak kademe yöneticilerin üzerine düşen birtakım sorumluluklar vardır (Al Ariss vd., 2014; Serim Bahadınlı, 2013; Dries ve Pepermans, 2012; Atlı, 2012; Demircioğlu, 2010; Çırpan ve Şen, 2009; Altınöz, 2009; Oehley, 2007; Ceylan, 2007).

Bir işletmenin tepe yöneticisi aslında yeteneği yöneten kişidir. General Electric'in eski CEO'su olan Jack Welch kendisini 'yüksek ücret paketine sahip bir insan kaynakları yöneticisi' olarak tanımlamıştır. Bir işletmede tepe yönetimi işletmenin stratejilerini eylemlere dönüştürecek işgörenlerini tek tek kazanma sorumluluğunu üstünde taşır (Atl1, 2012: 115). Eski bakış açısına göre, insanların yönetilmesinden sorumlu olarak insan kaynakları görülürken, yeni bakış açısına göre CEO'dan başlayarak bütün yöneticilerin kendi yetenek havuzlarının güçlendirilmesinden sorumlu olduğu dile getirilmektedir (Michaels, 2001: 16). Peters (2006: 12) başarılı liderleri 'yetenek fanatikleri' olarak adlandırmakta ve başarılı liderlerin yetenekli işgörenlere sahip olma konusunda ilgili işgörenlerin kendilerini geliştirip yaratıcı yönlerini ortaya koyabilecekleri işletme 


\section{H. Boz 13/4 (2021) 3236-3264}

ortamını sağlamakla görevli olduklarını dile getirmektedir. Peters'a (2006: 12-13) göre yetenek fanatiği liderlerin işgörenleri her zaman ön planda tutma, zamanlarının önemli bir bölümünü yetenekli işgörenlerin nasıl yönlendirileceği konusuna ayırma, her zaman en iyi için çalışma, işgörenlerin beklentilerine kulak verme, aldığı eleştirileri dikkate alma, işgörenlerin hak ettiği farklılaştırılmış ücretleri verme gibi sorumlulukları vardır.

Son yıllarda yetenek yönetimi, çoğu işletmenin insan kaynakları bölümlerinin temel başarı faktörleri içerisinde yer almaya başlamıştır. İşletmelerin insan kaynakları bölümlerinin başarılı olmasında en önemli sorumluluk, yetenekli işgörenlerin işletmeye çekilmesi ve onlardan etkin bir şekilde yararlanılmasını sağlayan yetenek yönetimi anlayışının benimsenmesidir (Pepe, 2007: 208). İnsan kaynakları bölümü 'yetenek yöneticisi' rolüyle yetenek yönetimi sistemini tanımlayan, altyapısını hazırlayan, yöneten, sistemin sürekli geliştirilmesini üstlenen, taraflar arası koordinasyonu sağlama görevini üstlenen yeteneğe ve üstün performansa dayanan sürdürülebilir bir örgüt kültürünün oluşturup denetleyenidir. Bu bağlamda, yeteneğe bakış açısının değiştirilmesi, yeteneklerin işletmeye çekilmesi, doğru yeteneklerin seçilmesi ve işletmeye uyumlu hale getirilmesi, yeteneklerin geliştirilmesi ve elde tutulması insan kaynakları bölümünün insiyatifinde gerçekleştirilir (Atlı, 2012: 117-118).

Yetenek yönetimi süreçlerinin başarılı şekilde yerine getirilebilmesinde sorumluluk taşıyan bir kesim de orta kademe yöneticilerdir. Yetenek yönetimi stratejisinin başarısı işletme içinde iyi şekilde sürdürülmesine bağlıdır. Yetenek yönetiminde üstlendikleri rolleri ile orta kademe yöneticiler astlarının işletmede kalma kararı vermeleri üzerinde de son derece etkili olmaktadırlar (Oehley, 2007: 23). Orta kademe yöneticiler yetenek yönetiminin sahada başarılı şekilde uygulanmasında çok kritik rol üstlenmektedirler. Başka bir anlatımla, potansiyelli işgörenleri yetiştirip geliştirecek olanlar ne tepe yönetim ne de insan kaynakları bölümüdür. Potansiyelli işgörenleri yetiştirecek olanlar orta kademe yöneticileridir. Böyle bir sorumlulukları olmakla birlikte, bazı yöneticilerin bu rollerini yerine getirmeme yönünde direnç sergiledikleri de görülebilmektedir. Bu konuda etkili olan gerekçelerden birisi, potansiyelli adayların yetiştirilmesinin yük olarak görülmesi ve zaman harcamayı gerektirmesidir. Yöneticilerin ikinci gerekçesi ise, yetiştirdikleri potansiyelli adayların zamanla kendi yerlerini alabileceği endişesidir. Bu direncin önüne geçmek için tepe yönetiminin kararlılığı ve açık iletişimle bölüm yöneticilerinin kaygılarının önüne geçmesi önem taşımaktadır (Çırpan ve Şen, 2009: 115-116). Orta kademe yöneticiler tepe yönetimi ve alt kademeler arasında üstlendiği köprü vazifesiyle yetenek yönetiminin işgörenlerce benimsenmesinde yönetimi temsil eder (Atl1, 2012: 121). Orta kademe yöneticiler, bir taraftan bireysel yıldız işgörenlerin gelişmeleri için katkı sağlarken, diğer taraftan üst düzey yöneticilere ve insan kaynakları yetkililerine işletme için dengeli bir liderlik geliştirme sisteminin oluşturulması ve işleyişinin sağlanmasına yardımcı olmak durumundadırlar (Cohn vd., 2005: 61). Kilit önemde olan orta kademe yöneticilerin sahip oldukları 'yetenek yönetimi yetkinlikleri' (Oehley, 2007: 16) yetenekli işgörenlerin cezbedilmesi, işletmeye alınması, eğitilip geliştirilmesi ve elde tutulması açısından çok değerli görülmektedir.

Bu bağlamda, Oehley (2007) yöneticilerin yetenek yönetimi sürecinde üstlendikleri önemli rollerle bağlantılı olarak ve alanyazına dayandırarak orta kademe yöneticilerde olması gereken yetenek yönetimi yetkinliklerini ortaya koymuştur. Yetenek yönetimi yetkinlikleri "yöneticilerin işletme için arzu edilen özellikli iş sonuçlarına ulaşmak için yetenekli işgörenleri cezbetmek, seçmek, işletmeye tutkun hale getirmek, geliştirmek ve elde tutmak için gereksinim duyulan davranış desenlerinin bütünüdür" biçiminde ele alınabilir (Oehley, 2007: 16). Yöneticilerin yetenekli işgörenleri yönetirken sahip olmaları beklenen yetkinlikler; 'yetenek yönetimi zihniyeti sergileme', 'yeteneği cezbetme ve işe alma', 'yetenekli işgörenleri belirleme ve farklılaştırma', 'yetenekli işgörenleri geliştirme', 'olumlu ilişkiler kurma ve geliştirme', 'anlamlı ve iddialı iş sağlama', 'adil davranma ve ödüllendirme', 'iş-yaşam dengesini yönetme' olmak üzere ele alınmaktadır (Oehley, 2007: 61). Yetenek yönetimi yetkinliklerinin ne anlam ifade ettiği Tablo 1'de ele alınmaktadır. 


\section{H. Boz 13/4 (2021) 3236-3264}

Tablo 1. Yöneticilerin Yetenek Yönetimi Yetkinliklerinin Boyutları ve Tanımları

Yetenek Yönetimi Zihniyeti Sergileme: İşletmenin diğer işletmelerden daha iyi performans ortaya koymasını sağlayacak biçimde, işletmenin bütün düzeylerinde daha iyi yeteneklere sahip olma konusunda 1srarlı ve sürekli bir inanç sergileme. İşletmede bu görüşünü düzenli olarak vurgulama.

Yeteneği Cezbetme ve İşe Alma: İşinin ehli ve işine kendini adamış işgörenleri işletmeye cezbetme ve işe alma. İşörenlerin doğru teknik uzmanlıklara ve başarı oryantasyonu ve motivasyonuna sahip olmasını sağlama. Yetenekli İşgörenleri Belirleme ve Farklılaştırma: İşgörenleri değerlendirmede uygun yönetsel kararları almak ve uygun eylemleri gerçekleştirmek amacıyla, değişik düzeylerdeki işgörenleri performans düzeylerine göre belirleme ve farklılaştırma.

Yetenekli İşgörenleri Geliştirme: İşgörenlerin gelişim gereksinimlerini doğru şekilde değerlendirme, bütün işgörenlerin potansiyellerini tam olarak geliştirmeleri için fırsatlar ve olanaklar sağlama.

Olumlu İlişkiler Kurma ve Sürdürme: Kişilerarası farkındalığın önemini anlama ve işgörenlerle iyi ilişkiler kurma ve sürdürme konusunda kabiliyete sahip olma.

Anlamlı ve İddialı İs Sağlama: Astlara işletmenin stratejik yönelimi ve astın bağlı bulunduğu bölümün stratejik yönelimi için bireysel katkı sunma olanağı tanıma. İşgörenlere, onların işletmeye tutkunluklarını sağlamak için mücadele gerektiren iddialı aktif iş fırsatları yaratma.

Adil Davranma ve Ödüllendirme: İşgörenlerin gösterdikleri başarının farkında olma ve buna uygun şekilde işgörenlere ödüllendirme ve tanınma sağlama.

İş Yaşam Dengesini Yönetme: İşgörenlerin kişisel ve aile yaşamları üzerinde olumsuz etki bırakabilecek iş faktörlerini kontrol etme.

Kaynak: Oehley, 2007: 61.

\section{Çalışmaya Tutkunluk}

Çalışmaya tutkunluk, Schaufeli vd. (2002: 74) tarafından kısaca "dinçlik, adanmışlık ve yoğunlaşma özelliklerini içeren işle ilgili olumlu ve tatminkâr bir zihinsel durum" biçiminde tanımlanmaktadır. Roberts ve O’Davenport (2002: 21) ise çalışmaya tutkunluğu, "bireyin işini yaparken şevk duyması ve işiyle bütünleşmesi" olarak tanımlamış ve çalışmaya tutkunluğu yüksek olan bireylerin işleriyle ilgili kendi kendilerini kolaylıkla motive edebildiklerinden söz etmiştir. Çalışmaya tutkunluk, örgüte tutkunluk (organizational engagement) ile birlikte işgören tutkunluğunun (employee engagement) iki boyutundan birisidir (Saks, 2006: 604). Çalışmaya tutkun işgörenler müşterilerinin ve adına çalıştıkları örgütlerinin istedikleri sonuçları elde edebilmek için diğer işgörenlere oranla daha sıkı ve verimli biçimde çalışma eğilimindedirler. Çalışmaya tutkun bireylerin enerjileri yüksektir ve bu bireyler işleriyle güçlü şekilde özdeşleşmişlerdir. Çalışmaya tutkunluğu yüksek olan bireyler işlerine karşı hevesli ve çalışırken zamanın uçup gittiği hissine kapılan bireyler olarak dikkat çekmektedir. Günümüz işletmeleri proaktif hareket edebilen, kendi profesyonel gelişimi için sorumluluklar alabilen, yüksek performans standartlarına bağlllık gösteren çalışmaya tutkun bireylerin arayışı içerisindedir (Bakker vd., 2008: 188).

Çalışmaya tutkunluğun üç ana boyutu dikkat çekmektedir. Bunlar, dinçlik, adanmışlık ve yoğunlaşmadır. Dinçlik işgörenin yüksek düzeyde enerjiye sahip olması ve çalışırken zihinsel olarak dirençli, işiyle ilgili gayret gösterirken istekli, işinde zorluklarla karşılaştığında sabırlı olabilen, yılmayıp sebat eden özelliklerle tanımlanmaktadır. Çalışması sırasında kendini dinç hisseden birey yaptığı işle güdülenmekte olup, karşılaşabileceği zorluklara rağmen sabırla işini yapmaya devam edecektir. Diğer bir boyut olan adanmışlık işgörenin işine verdiği önemi ve işine karşı hissettiği aitlik duygusunu nitelemektedir. Çalışmaya adanmış olan işgörenler yaptıkları işin ilgi çekici olduğunu, mücadele gerektirdiğini, bir amaca hizmet ettiğini ve anlamlı olduğunu düşünmektedirler. Bunun yanında, yaptıkları iş işgörenlere ilham vermektedir. Bundan dolayı, işgörenler işlerini hevesle yapmaktadırlar ve işleriyle gurur duymaktadırlar. Çalışmaya tutkunluğun son boyutu olan yoğunlaşma, bireyin yaptığı işe tamamen yoğunlaşıp odaklanmasını ve mutlu bir şekilde çalışmaya dalmasını ifade etmektedir. Bu boyut bağlamında, birey çalışırken yaptığı işe kendisini kaptırmakta, zamanın nasıl geçtiğini anlamamakta ve çalışma sırasında mola vermekte güçlük yaşamaktadır (Alarcon ve Lyons, 2011: 464; Turgut, 2011: 156; Schaufeli vd., 2002: 74). Adanmışlık ve dinçlik boyutları çalışmaya tutkunluğun ana boyutları olarak değerlendirilirken, yoğunlaşma çalışmaya tutkunluğun bir sonucu olarak ele alınmaktadır (Schaufeli ve Bakker, 2004: 295). 


\section{Duygusal Bă̆glilı}

Devam bağl1lığı ve normatif bağl1lıkla birlikte, örgütsel bağlılığın üç bileşeninden birisi olan duygusal bağl1lık (Meyer ve Allen, 1997), işgörenleri örgüte duygusal açıdan yaklaştıran ve onları çalıştıkları örgütün bir parçası oldukları için mutlu olmalarını sağlayan bağlılık tipi olarak ele alınmaktadır (Wiener, 1982: 423). Duygusal bağlılık, örgütsel amaçları benimseme, onlara bağlanma ve onunla özdeşleşme ile ilgili olumlu duygulara sahip olmak şeklinde ele alınabilir. Duygusal bağlılık, örgütün amaç ve kurallarına karşı duyulan saygı, yöneticilere duyulan sevgi ve saygı, duygusal yakınlık, örgütsel vizyon ve misyonun paylaşılması ile oluşan bağlılık türü olarak görülmektedir (Tutar, 2007: 106). Duygusal bağlılığ1 olan işgören kendisini örgütüne ait ve onun bir parçası olarak hissettiğinden, ilgili örgütte bulunmaktan büyük bir mutluluk duyar ve örgütten ayrılmayı aklına getirmez (Meyer ve Herscowitch, 2001). Genel itibariyle duygusal bağllı̆̆ın, işgörenlerin örgütün sahip olduğu değerleri ve hedefleri benimsemeleri ile ilgili olduğu görülmektedir. İşgören kendini örgütün ayrılmaz bir parçası olarak hisseder ve daima öyle kalmayı arzu eder. Duygusal bağlılık sadakat, adanmışlık, fedakârlık, dürüstlük gibi çoğu olumlu örgütsel davranışı güdülemektedir. Duygusal bağlılık, kişilik özellikleri ve işe ilişkin faktörlere ilişkin tutumsal bir olgu olup örgütsel hedefleri destekleme yönünde işgörenlerin gönüllülüğüne dayanmaktadır (Mir vd, 2002: 190; Jaros vd., 1993: 952).

Duygusal bağlılık, örgütsel bağl1lık boyutlarından belki de en önemlisidir. Duygusal bağlılı̆̆ yüksek olan bireyler örgütün amaçlarını benimsemekte ve bu amaçlarla kendisini özdeşleştirmektedir. Bireyler örgütün amaç ve kurallarına saygı duymakta ve yöneticilerini sevmektedir. Ayrıca duygusal bağlılığı yüksek olan bireyler örgütün misyon ve vizyonunu paylaşmaktadır. Duygusal bağlılık bireyin iş deneyimlerinin, işletmeye yönelik algılamalarının ve kişisel özelliklerinin birleşiminin sonucu olarak organizasyona karşı gelişen olumlu tutumların bir sonucu olarak ortaya çıkmaktadır (Çarıkçı ve Çelikkol, 2009: 159; Kaya ve Selçuk, 2007: 179).

\section{İş Tatmini}

Örgütsel davranışa doğrudan etkisi nedeniyle iş tatmini endüstriyel ve örgütsel psikoloji alanyazınında hatırı sayılır bir öneme sahiptir (Baş, 2002: 19). İş tatmini iki ana nedenden ötürü alanyazında en çok araştırılan konular arasına girmektedir. İlk olarak, iş tatmini çalışma koşullarının sorumluluk, görev çeşitliliği ve iletişim gibi bireye özgü değerlendirilmesi ile ilgilenenler için önem taşır. İkinci olarak ise, iş tatminsizliğinin işe devamsızlık, örgütsel verimliliğin düşmesi, işle ilgili dalgalanmalar yaşanması ve işletmenin sabote edilmesi gibi çalışma yaşamına ilişkin sorunların ana sebebi olarak görülmesidir. İki neden birlikte değerlendirildiğinde iş tatmininin, çalışma koşulları ile bu çalışma koşullarının bireysel ve örgütsel sonuçları arasında bağlantı kuran önemli bir kavram olarak dikkat çektiği söylenebilir (Dormann ve Zapf, 2001: 483).

İş tatmini ile ilgili yapılan araştırmalar verimlilik, devamsızlık ve işgören devri gibi iş ile ilgili davranışların ortaya konulmasında önemli görülmektedir (Oshagbemi, 1999). Özellikle işgörenlerin elde tutulmasının temelleri konusunda ilgili alanyazında iş tatmini en kilit alanlar arasında yer almaktadır (Gaylard vd., 2005). $\mathrm{Bu}$ nedenle özellikle işletmelerin yetenek yönetimi uygulamalarının da işgörenlerin iş tatmini üzerindeki etkisini göz önünde bulundurmak, işgörenlerin elde tutulması konusundaki gidişatla ilgili ipuçları verebilecektir.

İş tatmini geniş anlamda "bireylerin işlerine karşı sahip olduğu genel tutumu" ifade etmektedir (Greenberg ve Baron, 2000: 170). İş tatmini, "bir işgörenin genel olarak işin kendisine veya işin belirli birtakım yönlerine karşı hissetmiş olduğu duygular ve tutumlardır" biçiminde de tanımlanabilmektedir (Aşan ve Özyer, 2008: 135). İş tatmini işgörenlerin işlerinden umduklarını bulmasının sonucu olarak ortaya çıkan olumlu bir tutuma işaret etmektedir (Eren, 1996: 234). İş tatmini işgörenlerin işlerini sevmeleri ölçüsünde değerlendirilir. İşgörenler algılarına dayalı olarak işleri ve iş çevrelerine karşı olumlu ya da olumsuz tutum geliştirir. İşgörenin iş çevresi işgörenin gereksinimlerini, değerlerini ve kişisel karakteristiklerini karşıladıkça, iş tatmininin düzeyi yükselecektir (Abraham, 2012: 27).

İş tatminini içsel iş tatmini ve dışsal iş tatmini olarak iki boyuta ayırarak ele almak olanaklıdır. İçsel iş tatmini bireyin, işini iyi yapması ya da üstlendiği görevleri başarıyla yerine getirmesinden ötürü sağladığı kazanımlara ilişkin değerlendirmesidir. Diğer yandan dışsal iş tatmini ise, bireyin yönetici ya da işletme tarafından kendisine sunulan statü, tanınma ve terfi gibi kazanımlara ilişkin değerlendirmeleridir. İçsel iş 


\section{H. Boz 13/4 (2021) 3236-3264}

tatmini daha çok iş ile ilgili iken, dışsal iş tatmini ise daha çok işletmenin kimliği ve özelliği ile ilgilidir (Gürbüz, 2010: 232).

\section{İsten Ayrulma Niyeti}

İşten ayrılma niyeti bir işgörenin davranış niyetlerinden bahseder ve "bilinçli ve planlanmış biçimde işletmeyi terk etmeye niyetlenmek" olarak tanımlanabilmektedir (Tett ve Meyer, 1993: 260). Rusbult vd. (1988: 599) işten ayrılma niyetini, işgörenlerin istihdam koşullarından tatminsiz olmaları durumunda gösterdikleri yıkıcı ve aktif bir eylem şeklinde ele almışlardır. Mor Barak vd.'ne (2001: 628) göre işten ayrılma niyetinin sonrasında ekonomik, psikolojik ve sosyolojik boyutları olan işgören devrinin ve devamsızlık düzeylerinin artmasına yol açması, tüm örgütler bakımından işten ayrılma niyetinin tespitini gerekli kılmaktadır.

Özellikle yüksek performans gösteren yetenekli işgörenlerin işletmeden ayrılması işletmeler tarafından arzu edilmeyen bir durum olarak görülmektedir. İşten ayrılma öncesinde işgörenlerin işten ayrılmaya niyetlenmesi işten ayrılma davranışı açısından önemli bir sinyal olmakta, niyet aşamasında bunun nedenlerinin tespit edilip ortadan kaldırılması işgörenin kazanılması anlamında işletmelere yol gösterici olabilmektedir (Arı vd., 2010: 144). Yapılan birçok çalışma çoğu durumda bireyin işgören devrinin en iyi tahmincisinin işten ayrılma niyeti olduğunu göstermiştir. İşten ayrılma niyeti işgücü devri kararlarının en önemli ve doğrudan öncülüdür (Mitchell vd., 2001; Griffeth vd., 2000; Currivan, 1999; Tett ve Meyer, 1993; Arnold ve Feldman, 1982).

\section{Araştırma Hipotezlerinin Geliştirilmesi}

Çalı̧̧manın bu bölümünde hipotezlere temel oluşturacak biçimde yetenek yönetimi ile çalışmaya tutkunluk, duygusal bağlılık, iş tatmini ve işten ayrılma niyeti ilişkileri ve çalışmaya tutkunluk, duygusal bağlılık ve iş tatmininin aracılık rolleri alanyazında yapılan çalışmalara dayalı olarak irdelenmektedir.

Oehley (2007) yöneticilerin yetenek yönetimi yetkinlikleri ile işgörenlerin işten ayrılma niyeti, duygusal bağlılıkları ve iş tatminlerinin ilişkilerini araştırdığı çalışmada, yöneticinin 'yeteneği cezbetme ve işe alma' yetkinliği ile işgörenin 'örgütsel iş tatmini' arasında anlamlı ve pozitif yönlü orta düzeyde ilişki tespit etmiştir. Ayrıca çalışmada, yöneticinin 'adil davranma ve ödüllendirme' yetkinliği ile işgörenin 'yöneticiden tatmin'i arasında anlamlı ve pozitif yönlü orta düzeyde ilişki ölçülmüştür. Bunun yanında araştırmada, yöneticilerin 'yeteneği cezbetme ve işe alma' yetkinliği ile işgörenlerin işten ayrılma niyeti arasında işgörenlerin 'örgütsel tatmin'inin aracılık rolü üstlendiği de saptanmıştır (Oehley, 2007: 107-117).

Sivanesan (2014) bilişim şirketinde görev alan ve yetenekli işgören olarak belirlenmiş olan, çoğunluğu takım lideri ve yöneticisi olan işgörenlere yönelik araştırmasında yönetici yetenek yönetimi yetkinliklerinden yeteneği cezbetme ve işe alma ile iş tatmini arasında anlamlı ve pozitif ilişki; yetenekli işgörenleri geliştirme ile duygusal bağlılık arasında anlamlı ve pozitif ilişki; olumlu ilişkiler kurma ve geliştirme ile duygusal bağlılık arasında anlamlı ve pozitif ilişki; olumlu ilişkiler kurma ve geliştirme ile işten ayrılma niyeti arasında anlamlı ve negatif ilişki saptamıştır. Bunun yanında araştırmada, anlamlı ve iddialı iş sağlama ile iş tatmini arasında anlamlı ve pozitif ilişki; anlamlı ve iddialı iş sağlama ile işten ayrılma niyeti arasında anlamlı ve negatif ilişki; adil davranma ve ödüllendirme ile iş tatmini arasında anlamlı ve pozitif ilişki; adil davranma ve ödüllendirme ile işten ayrılma niyeti arasında anlamlı ve negatif ilişki ve iş-yaşam dengesini yönetme ile iş tatmini arasında anlamlı ve pozitif ilişki tespit edilmiştir (Sivanesan, 2014: 24-27).

Alias vd.'nin (2014) araştırmasında bilgi teknolojileri örgütlerinde yetenek yönetimi uygulamaları (yönetsel destek, işgören kariyer geliştirme ile ödüllendirme ve tanınma sağlama), işgören tutkunluğu ve işgörenin elde tutulması arasındaki ilişkileri araştırmış ve yönetimi uygulamaları ile işgören tutkunluğu arasında anlamlı ve pozitif ilişki bulunmuştur. Bunun yanında çalışmada, çalışmaya tutkunluğu da içine alan işgören tutkunluğunun yetenek yönetimi uygulamaları ile işgörenin elde tutulması arasında aracılık rolü üstlendiği bulunmuştur (Alias vd., 2014: 227).

Serim Bahadınlı'nın (2013) işletmelerin yetenek yönetimi uygulamalarının işgörenlerin iş tatmini ve örgütsel bağlılıkları üzerindeki etkilerini araştırdığı çalışmada, yetenek yönetimi uygulamaları algısının, işgörenlerin iş tatmini ve örgütsel bağlllıkları üzerinde etkili olduğunu ortaya koymuştur.

Hughes ve Rog (2008) yaptıkları alanyazın gözden geçirmesine dayalı araştırmanın sonuçları, etkin şekilde uygulanmış yetenek yönetimi stratejisinin işgörenlerin işe alınması ve elde tutulması ile işgören 


\section{H. Boz 13/4 (2021) 3236-3264}

tutkunluğunun arttırılması gibi yararlar sağlayabileceğini ortaya koymuştur. Ayrıca araştırmacılara göre, bu çıktılar işletmenin operasyonel ve finansal çıktılarının arttırılması ile de ilişkili görülmektedir (Hughes ve Rog, 2008: 743).

Festing ve Schafer (2014) yaptıkları çalışmada, yetenek savaşında üstün gelmek için işletmelerin, Baby Boomer kuşağından (1946-1964 arasında doğan kuşak) çok, X ve Y kuşaklarının eğitim, geliştirme ve kariyer olanaklarını arttırmak ve bu sayede onları tutkun işgörenler haline getirmek için kapsamlı yetenek yönetimi faaliyetleri gerçekleştirmenin, yetenekli işgörenlerin elde tutulmasında çok kritik önemde olduğu dile getirilmiştir (Festing ve Schafer, 2014: 262).

Aljunaibi (2014) yaptığı araştırmada, yetenek yönetimi uygulamaları (yeteneği geliştirme, tanınma sağlama, liderlik geliştirme) ile işgören tutkunluğu arasında anlamlı ve pozitif yüksek düzeyde ilişki olduğunu tespit etmiştir. Barkhuizen vd.'nin (2014) yaptığı çalışmada ise, bazı yetenek yönetimi boyutlarının (yönetimin bağlllı̆̆l, yetenek değerlendirme süreci, yeteneği geliştirme ve performans yönetimi) çalışmaya tutkunluğun tüm boyutları ile anlamlı ve pozitif ilişkili olduğunu saptamıştır.

Barkhuizen vd. (2015) öğretmen üzerine yaptığı araştırmada, yetenek yönetimi ve yetenek yönetimi boyutları (işgücü planlama, yeteneği edinme, yetenek bağlılığı, yeteneği geliştirme, performans yönetimi, yeteneği elde tutma) ile öğretmenlerin işten ayrılma niyeti arasındaki ilişkiyi araştırmış, yetenek yönetimi ve yetenek yönetimi boyutları ile öğretmenlerin işten ayrılma niyeti arasında anlamlı ve negatif ilişki tespit etmiştir.

Tanton'un (2007) vaka çalışmasına dayalı gerçekleştirilen araştırmanın genel sonucu, işgörenin elde tutulmasında yetenek yönetiminin rolünün yadsınamayacağını göstermiştir. Çalışmanın sonuçları, işletmelerin yetenekli işgörenlerin işletmeden ayrılmasına yol açan gönüllü işgücü devrinin önüne geçmesi konusunda iş tatmini, yetenek yönetimi ve işgöreni elde tutma ile ilgili tüm faktörlere odaklanma gereksinimi duyduğunu göstermiştir (Tanton, 2007: 2-5).

Chami-Malaeb ve Garavan (2013) yaptıkları araştırmada, işletmelerin yetenek geliştirme uygulamaları ve liderlik geliştirme uygulamalarının işgörenlerin duygusal bağllık ve işletmede kalma niyeti ile anlamlı ve pozitif ilişkili olduğunu tespit etmiştir. Ayrıca bu araştırmada, duygusal bağlılığın yetenek geliştirme uygulamaları ile işletmede kalma niyeti arasında kısmi aracı etkisi olduğu, liderlik geliştirme uygulamaları ile işletmede kalma niyeti arasında ise tam aracı etkisi olduğu da bulunmuştur.

Darvish vd.'nin (2012) araştırmasında, yönetici yetenek yönetimi yetkinlikleri boyutlarının (yetenek yönetimi zihniyeti sergileme, yeteneği cezbetme ve işe alma, yetenekli işgörenleri belirleme ve farklılaştırma, yetenekli işgörenleri geliştirme, olumlu ilişkiler kurma ve geliştirme, anlamlı ve iddialı iş sağlama, adil davranma ve ödüllendirme ve iş-yaşam dengesini yönetme) işgörenin işten ayrılma niyeti ile anlamlı ve negatif ilişkili olduğu tespit edilmiştir.

Du Plessis vd. (2015) çalı̧̧masında algılanan yetenek yönetimi uygulamaları ile işgörenlerin işten ayrılma niyeti arasında anlamlı ve negatif orta düzeyde ilişki tespit etmiştir. Ayrıca araştırmanın sonuçları, algılanan yetenek yönetimi uygulamaları ile işten ayrılma niyeti arasında algılanan örgütsel destek ve algılanan yönetici desteğinin aracı ya da düzenleyici rolü olmadığını göstermiştir.

Akbaş (2013) Türkiye' de bir banka üzerinde gerçekleştirdiği vaka çalışmasında yetenek yönetimi ile yetenekli işgörenlerin elde tutulması arasındaki ilişkiyi incelemiş ve işletmenin gelecekteki gereksinimlere yönelik güçlü liderlik hattı kurmak için yetenek yönetimi sistemlerinin özenli biçimde kurulması ve kullanılması gerektiğini ortaya koymuştur. Ayrıca araştırma, gelişimi için yatırım yapılmış olan yetenekli işgörenlerin işten ayrılma olasılığının daha düşük olduğunu ortaya koymuştur.

Gussenhoven (2009) yetenekli işgören olarak tanımlanmış bulunan işgörenlere yönelik araştırmasında, yetenek yönetimi uygulamalarının duygusal bağlılık üzerindeki etkisinin psikolojik sözleşme aracılığıyla açıklanabileceğini ortaya koymuştur. Ping (2011) yaptığı çalışmada, yetenek yönetimi uygulamalarının (yeteneği cezbetme, yeteneği seçme, yeteneği tutkun hale getirme, yeteneği geliştirme ve yeteneği elde tutma) örgütsel bağlılığa (duygusal bağlllık, devam bağlılığı, normatif bağlllık) etkisini incelemiş ve yönetimi uygulamaları ile örgütsel bağlılık arasında anlamlı ve pozitif yönlü ilişki tespit etmiştir. Bu çalışmada, özellikle yetenek yönetimi uygulamalarının yeteneği tutkun hale getirme ve yeteneği geliştirme boyutlarının örgütsel bağlılığın farklı boyutları ile anlamlı ilişkilerinin olduğu görülmüştür. 


\section{H. Boz 13/4 (2021) 3236-3264}

Hamidi vd.'nin (2014) kamu örgütlerine yönelik çalışmasında, bütün yetenek yönetimi uygulamalarının (yetenekleri seçme, işe alma, kullanma, geliştirme ve elde tutma) iş tatmini ile anlamlı ve pozitif ilişkili olduğunu ortaya koymuştur. Luna-Arocas ve Morley (2015) ise, yetenek yönetimi zihniyeti sergileme yetkinliğinin iş tatmini üzerinde doğrudan, iş performansı üzerinde de dolaylı etkisinin olduğunu tespit etmiştir. Ayrıca sözü edilen çalışmada, iş tatmini yetenek yönetimi zihniyeti sergileme yetkinliği ile iş performansı arasında aracılık rolü üstlendiği de saptanmıştır.

Khah vd.'nin (2014) araştırmasının sonuçları, işgörenlerin yetenek yönetimi algısının iş tatmini, sadakat ve işgören tutkunluğunda etkili bir role sahip olduğunu göstermiştir. Ayrıca araştırmada, yetenek yönetiminin işgören tutkunluğu üzerinde iş tatmini ve sadakat vasıtasıyla dolaylı etkiye sahip olduğu da saptanmıştır.

Hoogervorst (2009) yaptığı çalışmada, yetenek yönetimi uygulamaları düzeyinin işten ayrılma niyeti üzerindeki etkisinde psikolojik sözleşmenin aracılık rolünün olduğunu tespit etmiştir.

Kamil vd. (2011) Malezya'da altı şirketin insan kaynakları uzmanları ile gerçekleştirdikleri mülakatlar sonucunda, yetenek yönetiminin işgörenin elde tutulmasında gözönünde bulundurulması gereken bir strateji olduğunu tespit etmiştir. Mülakatlara göre, bahsi geçen bu strateji işe alma, seçme, eğitim ve geliştirme ve performans yönetimi gibi insan kaynakları faaliyetlerini içine almaktadır. Çalışmaya göre, yetenek yönetimi sayesinde yetenekli işgörenin tutkunluğunun sağlanması ve elde tutulması örgütsel başarı ve performansın geliştirilmesi için gerekli görülmektedir (Kamil vd., 2011: 147).

Sweem'in (2009) karma bir yöntem kullanılarak gerçekleştirilen araştırması, yetenek yönetimi stratejisinin anlamlı şekilde işgören tutkunluğunu arttırdığını tespit etmiştir. Bunun yanında bu araştırma, yetenek yönetiminin stratejik bir insan kaynakları/örgüt geliştirme faaliyeti olduğunu ortaya koymuştur.

Alanyazın incelendiğinde yetenek yönetimi ile işten ayrılma niyeti arasında çalışmaya tutkunluğun aracılık rolü üstlendiği çalışmaya rastlanmamakla birlikte, Alias vd. (2014: 227) yaptıkları araştırmada çalışmaya tutkunluğu da içine alan işgören tutkunluğunun yetenek yönetimi uygulamaları (yönetsel destek, işgören kariyer geliştirme ile ödüllendirme ve tanınma sağlama) ile işgörenin elde tutulması arasında aracılık rolü üstlendiğini saptamışlardır. Çalışmaya tutkunluğun işgören tutkunluğunun iki temel bileşeninden birisi olduğu düşünüldüğünde, çalışmaya tutkunluğun yetenek yönetimi ile işgörenin işten ayrılma niyeti arasında aracı rol üstlenebileceğini söyleyebiliriz. Bunun yanında alanyazına bakıldığında, çalışmaya tutkunluğun aracılık rolü üstlendiği başka bazı çalışmalar da vardır. El Badawy ve Bassiouny (2014) çalışmasında, işgören tutkunluğunun dönüşümcü liderlik ile işten ayrılma niyeti arasında aracılık rolü üstlendiği ortaya koymuştur. Yalabik vd. (2013), çalışmaya tutkunluğun duygusal bağlllık ile iş performansı ve işten ayrılma niyeti arasında tam aracılık rolü üstlendiğini tespit etmiştir. Ayrıca ilgili çalışmada, çalışmaya tutkunluğun iş tatmini ile iş performansı arasında tam, iş tatmini ile işten ayrılma niyeti arasında ise kısmi aracılık rolü üstlendiği de bulunmuştur. Agarwal ve Gupta'nın (2015) yaptıkları çalışmada ise, iş özellikleri ile işten ayrılma niyeti ilişkisinde çalışmaya tutkunluğun aracılık rolü üstlendiği tespit edilmiştir.

Alanyazında duygusal bağlılığın yetenek yönetimi ile işten ayrılma niyeti arasında aracı rolüne dikkat çeken pek araştırma olmamakla birlikte, Chami-Malaeb ve Garavan (2013: 4046) yaptıkları araştırmada duygusal bağllı̆ı̆ın işletmenin yetenek geliştirme uygulamaları ile işgörenin işletmede kalma niyeti arasında kısmi aracı etkisi olduğunu, işletmenin liderlik geliştirme uygulamaları ile işgörenin işletmede kalma niyeti arasında ise tam aracı etkisi olduğu bulgulamıştır. Buradan yola çıkılarak, duygusal bağlılığın yetenek yönetimi uygulamaları ile işten ayrılma niyeti arasında aracı rol üstlenebileceğini düşünmek yanlış olmayacaktır. Ayrıca, alanyazında duygusal bağlılığın aracılık rolü üstlendiği başka çalışmalar da söz konusudur. Ahmad ve Omar'ın (2010) araştırmasında, algılanan aile destekleyici çalışma kültürü ile işten ayrılma niyeti arasında anlamlı ve ters yönlü ilişki olduğu, ayrıca duygusal bağlılı̆̆ın bu ilişkide aracılık rolü üstlendiği tespit edilmiştir. Almutairi (2016) duygusal bağlılığın dönüşümcü liderlik tarzı ile işgörenin iş performansı arasındaki ilişkide aracılık etkisi olduğunu ortaya koymuştur. Camelo-Ordaz vd. (2011), insan kaynakları yönetimi uygulamalarının bilgi paylaşımı ile ilişkisinde duygusal bağlılığın aracılık etkisinin olduğunu tespit etmiştir.

Tanton (2007) vaka çalışması şeklinde gerçekleştirdiği araştırmada, yetenek yönetimi uygulamalarının yetersizliğinin işten tatminsizliğe yol açan nedenlerden biri olarak işgörenlerin işten ayrılmasına yol açıp açmadığını ve yetenek yönetiminin işgörenlerin örgütte tutulmasında pozitif rol üstlenip üstlenmediğini 
ortaya koymayı amaçlamaktadır. Çalışmanın genel sonucu, işgörenin elde tutulmasında yetenek yönetiminin rolünün yadsınamayacağını göstermiştir. Araştırmanın sonuçları işletmelerin yetenekli işgörenlerin işletmeden ayrılmasına yol açan gönüllü işgücü devrinin önüne geçilmesi konusunda iş tatmini, yetenek yönetimi ve işgöreni elde tutma ile ilgili tüm faktörlere odaklanma gereksinimi duyduğunu da işaret etmektedir (Tanton, 2007: 2-5). Bu çalışmada da görüleceği üzere, iş tatmininin yetenek yönetimi ile işten ayrılma niyeti arasında aracı bir rol üstlenebileceği söylenebilir. Alanyazında, iş tatmininin aracılık rolüne dikkat çeken başka bazı araştırmalar da dikkat çekmektedir. Serim Bahadınlı (2013) yaptı̆̆ı araştırmada, iş tatmininin yetenek yönetimi uygulamalarının soyut algısı ile örgütsel bağlılığın duygusal bağlılık, devam bağ lılı̆̆ 1 ve normatif bağlılık boyutları arasında kısmi aracı rolü üstlendiği sonucuna varmıştır. Anafarta (2015), iş tatmininin algılanan örgütsel destek ile işten ayrılma niyeti arasındaki ilişkide kısmi aracıllk etkisi olduğunu tespit etmiştir. Crow vd. (2012) ise, iş tatmininin örgütsel adalet algısı ile örgütsel bağllık arasında aracı rol üstlendiğini saptamışlardır.

Buraya kadar ele alınan tüm araştırma sonuçları ve değerlendirmeler ışığında araştırmada test edilecek hipotezler aşağıdaki biçimde geliştirilmiştir:

Hipotez 1: Yetenek yönetimi yetkinliklerinin işten ayrılma niyeti üzerinde doğrudan negatif bir etkisi vardır.

Hipotez 2: Duygusal bağlılık yetenek yönetimi yetkinlikleri ile işten ayrılma niyeti arasında aracılık etkisine sahiptir.

Hipotez 3: Çalışmaya tutkunluk yetenek yönetimi yetkinlikleri ile işten ayrılma niyeti arasında aracılık etkisine sahiptir.

Hipotez 4: İş tatmini yetenek yönetimi yetkinlikleri ile işten ayrılma niyeti arasında aracılık etkisine sahiptir.

\section{Yöntem}

\section{Araştırmanın Amacı ve Modeli}

Çalışmanın temel amacı, Türkiye'de faaliyet gösteren ve yetenek yönetimi uygulamaları ile öne çıan bankaların yöneticilerinin sahip olduğu yetenek yönetimi yetkinliklerinin, işgörenlerin işten ayrılma niyeti üzerindeki etkisini ve bu ilişkide işgörenlerin duygusal bağlllıklarının, çalışmaya tutkunluklarının ve iş tatminlerinin aracı rol üstlenip üstlenmediklerini araştırmaktır. Araştırmada yanıtı aranan sorular olarak 'Yöneticilerin yetenek yönetimi yetkinlikleri işgörenlerin işten ayrılma niyeti üzerinde etkili midir?' ve 'Yöneticilerin yetenek yönetimi yetkinlikleri ile işgörenin işten ayrılma niyeti ilişkisinde duygusal bağllık, çalışmaya tutkunluk ve iş tatmininin aracı etkisi var mıdır?' şeklindedir.

Çalışmada; bağımlı değişken işgörenin işten ayrılma niyeti iken, bağımsız değişken yöneticilerin yetenek yönetimi yetkinlikleridir. Bunun yanında, yöneticilerin yetenek yönetimi yetkinliklerinin işgörenlerin işten ayrılma niyeti üzerindeki etkisine aracılık edebileceği düşünülen çalışmaya tutkunluk, duygusal bağlllık ve iş tatmini aracı değişken olarak ele alınmaktadır. Bu değişkenler göz önünde bulundurularak oluşturulan araştırma modeli Şekil 1'de görülmektedir. 


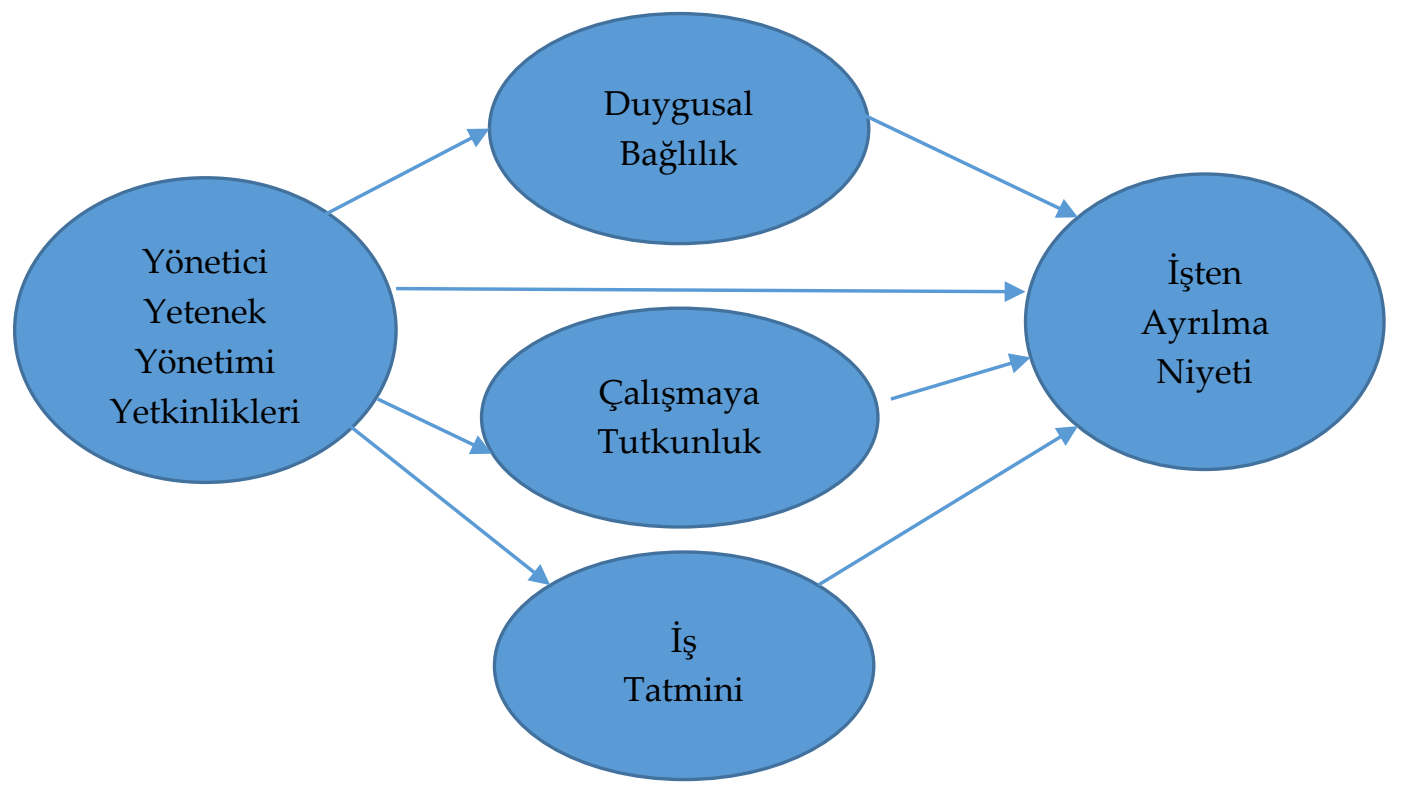

Şekil 1. Araştırma Modeli

\section{Araştırmanın Önemi}

Yenilikçi uygulamaları ve güncel yaklaşımları yoğun biçimde hayata geçiren bankacılık sektörü, Türkiye'de yetenek yönetimi uygulamalarının otomotiv sektörü, hızlı tüketim malları sektörü ve ilaç sektörü gibi sektörlerle birlikte en çok uygulandığı sektörler arasında yer almaktadır (Towers Watson, 2011). Alanyazın incelendiğinde, ülkemizde bankacılık sektörüne yönelik yetenek yönetimi çabalarını ele alan önemli sayıda akademik çalışmaya rastlanılmaktadır. Akbaş (2013) yaptığı çalışmada, bankacılık sektöründe vaka çalışması yoluyla yetenek yönetimi ile işgöreni elde tutma ilişkisini ele almıştır. Altunoğlu vd. (2015) yaptıkları vaka çalışmasıyla yetenek yönetimi uygulaması olan bir bankanın yetenek yönetimi uygulamaları ile bankanın olumlu iş sonuçları elde etmesi arasında pozitif ilişkinin olup olmadığını araştırmıştır. Demircioğlu (2010) çalışmasında özel bir bankanın yetenekli işgörenlerini uzun süreli istihdam edebilmesi için yapılandırdığı yetenek yönetimi programından ne şekilde yararlandığını, yetenek yönetimine ilişkin uygulamaların ne gibi etkilerinin olduğunu vaka üzerinden incelemiştir. Öner (2014) çalışmasında, Türkiye'de faaliyet gösteren bir bankaya yönelik gerçekleştirdiği vaka çalışması ile ilgili bankanın yetenek yönetimini nasıl ele aldığını, kuramsal çerçevede yer verilen bilgilerle bağlantılı olarak değerlendirmiştir. Yiğit ve Kaplan (2015), özel bir bankanın yetenek yönetimi yöneticisi ile gerçekleştirdikleri mülakat yoluyla, bankanın yetenek yönetimi sürecini irdelemişlerdir. Kanap Güngör (2013) bankacılık sektörü işgörenlerine yönelik ankete dayalı yaptığı araştırmada, işletmelerin yetenek yönetimi uygulamalarının işgören performansına etkisini ele almıştır. Karabıyık (2015) çalışmasında beş bankanın insan kaynakları ve yetenek yönetimi birimi uzmanlarıyla mülakatlar gerçekleştirmiş ve ilgili bankaların yetenekli işgörenlere yönelik uygulamaları 1şığında, ülkemizin bankacılık sektöründeki yetenek yönetimi uygulamalarını ortaya koymaya çalışmışır. Muslu (2013) yaptığı çalışmada, anket yoluyla ulaştığı kamu ve özel sektör bankalarının işgörenlerinin yetenek yönetimi uygulamalarına ilişkin algılarını ve bu algıların cinsiyet, yaş, eğitim düzeyi, medeni durum vb. gibi farklı demografik niteliklere göre farklılık gösterip göstermediğini araştırmıştır. Terlemez (2013) ise, Türkiye'nin önde gelen bankalarından birine yönelik yürüttüğü vaka çalışmasında yetenek yönetimi uygulamalarının bankaya olan etkilerinin incelenmesi, bankanın yetenekli işgörenleri uzun süreli elde tutabilmek için yetenek yönetimi uygulamalarından nasıl yararlandığı, yetenek yönetimi uygulamalarının olumlu ve olumsuz etkilerinin neler olduğu gibi konulara odaklanmıştır.

Türkiye'de yapılan ve yukarıda sözü edilen bankacılık sektöründeki yetenek yönetimi uygulamalarını konu alan akademik çalışmalara bakıldığında, çalışmaların çoğunlukla bir banka özelinde vaka çalışması şeklinde yürütüldüğü ve yetenek yönetimi uygulamalarının olası sonuçlarının bu işletme özelinde ele alındığı görülmektedir. Ayrıca yetenek yönetimi uygulamalarından beklenen olası bireysel ve örgütsel sonuçlar arasında rol oynayabilecek aracı değişkenleri ele alan akademik çalışmaya rastlanmamıştır. Bu bağlamda, yapılan bu nicel araştırmanın yetenek yönetimi uygulamaları ile tanınan beş farklı bankadan veri toplanarak gerçekleştirilmesi ve yetenek yönetimi uygulamaları ile işten ayrılma niyeti arasındaki ilişkide aracı rol 
üstlenebilecek değişkenleri araştırması açısından alanyazına anlamlı bir katkı sağladığı söylenebilir. Diğer yandan, bu çalışmanın yetenek yönetimi uygulamalarının hayata geçirilmesi noktasında çok önemli bir konumda yer alan yöneticilerin yetenek yönetimi yetkinliklerinin işgören bakış açısından değerlendirilmesi ve sözü edilen yetkinliklerin işgörenlerin duygusal bağlılıklarına, çalışmaya tutkunluklarına, iş tatminlerine ve işten ayrılma niyetlerine olası etkisinin görülmesi açısından akademik alanyazına ve uygulamacılara önemli bir katkı sağladığı söylenebilmektedir.

\section{Araştırmanın Kapsamı ve Sinırlilıkları}

Bu araştırma ülkemizde bankacılık sektöründe faaliyet gösteren ve yetenek yönetimi uygulamaları bulunan bankaların Antalya ili genelinde bulunan şubelerindeki yetenekli işgörenleri kapsamaktadır. Yetenek yönetimi uygulamaları bulunan bankaların tespitinde elektronik ortam taramaları ve Türkiye Bankalar Birliği'nde kayıtlı bulunan bankaların genel müdürlükleri ile kurulan iletişimden yararlanılmıştır. Bankacılık sektörün seçilmesinin ana nedeni, bu sektörün ülkemizde yetenek yönetimi uygulamalarının en geniş ve etkili şekilde uygulandığı sektörler arasında yer almasıdır. Bu nedenle uygulamanın bu sektördeki işgörenlere dönük yapılmasının yetenek yönetimi yetkinlikleri ve işten ayrılma niyeti ilişkisi hakkında daha sağlıklı veri sağlayacağı öngörülmüştür. Çalışmada bankacılık sektöründe faaliyet gösteren işletmelerin yetenekli olarak değerlendirilen işgörenlerinin görüş ve algıları esas alınmıştır. Maddi olanak ve zaman kısıtı dolayısıyla araştırma sadece Antalya ilinde yürütülmüştür.

\section{Araştırmanın Evreni ve Örneklemi}

Araştırmanın evrenini yetenek yönetimi uygulaması olan bankaların Antalya ilinde faaliyet gösteren şubelerindeki yetenekli işgörenler oluşturmaktadır. Türkiye Bankalar Birliği'nin verilerine göre Antalya ilinde faaliyet gösteren tüm banka şubelerinde (yetenek yönetimi uygulamaları olmayan bankalar da dahil) 31.12.2014 tarihi itibariyle 6025 kişi çalışmaktadır. Bu sayı yine aynı verilere göre, Akdeniz Bölgesi'nde 16851 kişi, Türkiye genelinde ise 200084 kişidir. İller özelinde bakıldığında Antalya; İstanbul (83636 kişi), Ankara (19746 kişi), İzmir (11272 kişi) ve Kocaeli'den (9419 kişi) sonra bankacılık sektöründe en fazla istihdamın olduğu beşinci il olarak dikkat çekmektedir (www.tbb.org.tr, 2015).

Araştırma çerçevesinde ulusal düzeyde yetenek yönetimi uygulamalarına sahip olduğu elektronik ortam taramaları ve genel müdürlük iletişimleri ile tespit edilen ve araştırmaya katılım konusunda olumlu yaklaşan beş bankanın farklı şubelerindeki değişik düzeylerdeki yetenekli olarak değerlendirilen işgörenlerden verilerin toplanması amaçlanmıştır. Tüm anket formunun oluşturulmasından ve pilot uygulamanın gerçekleştirilmesinden sonra, yetenek yönetimi uygulayan bankaların Antalya ili genelindeki şubelerinden öncesinde randevu alınarak işgörenlerin uygunluk durumuna göre ya yüz yüze anket uygulaması şeklinde ya da anket formunun bırakılıp daha sonra kapalı zarf içinde doldurulmuş olarak teslim alınması şeklinde uygulama gerçekleştirilmiştir. İşgörenlerin yetenekli işgören sınıfında değerlendirilip değerlendirilmediği konusunda şube yöneticilerinin beyanları dikkate alınmış ve yetenekli işgören olduğu belirtilen işgörenlere anketler 20 Temmuz 2015-15 Ekim 2015 tarihleri arasında uygulanmıştır. Anketlerin uygulanmasında olasılıklı olmayan örnekleme tekniklerinden kolayda örnekleme yöntemi tercih edilmiştir. Kolayda örnekleme yönteminde araştırmacı gereksinim duyduğu büyüklükte örnekleme ulaşıncaya kadar en kolay ve ulaşılabilir katılımcılardan veri toplamaya çalışmaktadır (Gürbüz ve Şahin, 2015: 130). 500 adet bastırılarak şubelere dağıtımı gerçekleştirilen anket formlarından 423'ü geri dönmüş, bunlardan tam ve eksiksiz olarak doldurulmuş olan 376'sı araştırmanın veri analizine dâhil edilmiştir. \%95 güvenilirlik düzeyinde evren büyüklügü 6000 kişiden oluşan bir gruptan 361, evren büyüklüğü 6500 kişiden oluşan bir gruptan ise 363 kişilik bir örnekleme ulaşılması kabul edilebilir görülmektedir (Gürbüz ve Şahin, 2015: 128). Araştırmanın evrenini oluşturan Antalya ilindeki tüm banka işgörenlerinin sayısı 6025 kişidir. Yani Antalya'da tüm bankacılar yetenekli işgören sınıfına dâhil edilmiş olsa bile, bu evrenden 363 kişilik bir örnekleme ulaşılması yeterli kabul edilebilmektedir. Kaldı ki, tam sayısı bilinmemekle birlikte yetenek yönetimi uygulayan bankalarda çalışan yetenekli işgören sayısı bunun da altında yer almaktadır. Bu açıdan değerlendirildiğinde 376 adet tam ve eksiksiz doldurulmuş anket formu \%95 güvenilirlik düzeyinde kabul edilebilir bir sayı olarak değerlendirilebilmektedir. 


\section{Araştırmada Kullanılan Ölçekler}

Araştırmada ele alınan modele ilişkin değişkenlerin ölçümünü ve hipotezlerin test edilmesini sağlamak amacıyla 5 ölçekten yararlanılmıştır. Ayrıca demografik özelliklerin tespitine yönelik 9 adet demografik ifadeye de anket formunda yer verilmiştir. Yetenek Yönetimi Yetkinlikleri Ölçeği (Talent Management Competency Questionnare) Oehley (2007) tarafından geliştirilmiş olup Türkçe uyarlaması bu çalışma kapsamında gerçekleştirilmiştir. Türkçe uyarlaması gerçekleştirilen Yetenek Yönetimi Yetkinlikleri Ölçeği 5'li Likert (1-Kesinlikle katılmıyorum, 5-Kesinlikle katılıyorum) şeklinde olup, orijinalinde 8 boyutlu ve 43 ifadeden oluşan bir ölçektir. İşgörenlerin çalışmaya tutkunluk düzeylerini belirlemek amacıyla 17 ifadeden oluşan ve Schaufeli vd. (2002) tarafından geliştirilip Turgut (2011) tarafından Türkçe'ye çevrilmiş olan Utrecht Çalışmaya Tutkunluk Ölçeği (Utrecht Work Engagement Scale-UWES) kullanılmıştır. Çalışmaya tutkunluk ölçeği 5'li Likert (1-Hiçbir zaman, 5-Her zaman) şeklinde tasarlanmıştır. İşgörenlerin duygusal bağlılıklarını ölçmek için 6 ifadeden oluşan Allen ve Meyer (1990) tarafından geliştirilen ve örgütsel bağlılık ölçeğinin parçası olan duygusal bağlılık ölçeği kullanılmıştır. Ölçek 5'li Likert (1-Kesinlikle Katılmıyorum, 5-Kesinlikle Katılıyorum) şeklindedir. Ölçekte yer alan üç ifade olumsuz şekilde oluşturulduğundan, veriler analiz için istatistik paket programına işlenirken ters yönlü puan girişleri gerçekleştirilmiştir. İşgörenlerin iş tatminini ölçmeye dönük 20 ifadeden oluşan Weiss vd. (1967) tarafından geliştirilen Minnesota İş Tatmini Ölçeği (Minnesota Satisfaction Questionnaire) kullanılmıştır. İş Tatmini Ölçeği 5'li Likert (1-Hiç memnun değilim, 5Çok memnunum) şeklindedir. İşörenin işten ayrılma niyetini ölçmeye dönük 4 ifadeden oluşan Rusbult vd.'nin (1988) işten ayrılma niyeti ölçeğinden yararlanılmıştır. Ölçek 5'li Likert (1-Kesinlikle Katılmıyorum, 5Kesinlikle Katılıyorum) şeklinde düzenlenmiştir.

\section{Bulgular}

\section{Araştırmaya Katılanların Betimleyici İstatistikleri}

Araştırmaya dâhil edilen 376 yetenekli işgörene ait betimleyici istatistiklere bakıldığında; katılımcıların $\% 48,7^{\prime}$ sinin kadınlardan, \%51,3'ünün erkeklerden oluştuğu, \%64,9 büyüklüğündeki önemli bir kesiminin 2635 yaş grubundaki çalışanlardan meydana geldiği, \%97,3'ünün lisans ya da lisansüstü eğitim derecesine sahip olduğu, \%59,6'sının evli, geri kalanının bekâr olduğu tespit edilmiştir. Çalışılan departman açısından bir değerlendirmeye gidildiğinde katılımcıların \%42,8'inin ilgili bankaların operasyon departmanlarında çalıştığı, bunu da \%28,5 ile bireysel bankacılık departmanında çalışanların takip ettiği görülmüştür. Çalışılan pozisyon açısından ele alındığında ise gişe yetkilileri $(\% 31,4)$ en çok katılım gösterenlerdir. Bunun yanında portföy yöneticilerinin $(\% 26,1)$ ve portföy yetkililerinin $(\% 26,5)$ oranları da katılımcılar içinde önemli bir düzeydedir. Araştırmaya katılanların genelde $0-5$ yıl arası $\left(\% 58,8^{\prime}\right.$ i) ya da 5 yıl üstü-10 yıl arası $\left(\% 30,6^{\prime}\right.$ sı) halen çalışmakta olduğu bankalarda çalıştığı görülmektedir. Sektörde çalışma süreleri açısından bakıldığında ise işgörenlerin $\% 44,9$ 'u 0-5 yıl arası sektörde iken, \%35,4'ünün 5 yıl üstü-10 yıl arası sektörde bulunduğu dikkat çekmektedir. Son olarak, ortalama aylık gelir düzeyi açısından işgörenlerin \%36,7'sinin 1501-2500 TL arası aylık gelire sahipken, \%27,7'sinin de 2501-3500 TL aralığında bir gelirinin olduğu tespit edilmiştir.

\section{Kullanılan Ölçeklere İlişkin Analiz Bulguları}

Ölçme araçlarının geçerlilik ve güvenilirlik analizleri bağlamında Yetenek Yönetimi Yetkinlikleri Ölçeği, Çalışmaya Tutkunluk Ölçeği ve İş Tatmini Ölçeği için Açıklayıcı Faktör Analizi (AFA) gerçekleştirilmiş; ölçeklerden elde edilen faktörlerin iç tutarlılıklarını belirlemek üzere güvenilirlik analizleri yapılmıştır. Bu analizler IBM SPSS 21.0 paket programı ile gerçekleştirilmiştir. Ayrıca bu ölçekler için IBM SPSS AMOS 22.0 yardımıyla Doğrulayıcı Faktör Analizleri (DFA) gerçekleştirilmiştir. Diğer yandan, tek boyut olarak değerlendirildiğinden faktör analizleri gerçekleştirilmeyen Duygusal Bağlılık Ölçeği ve İşten Ayrılma Niyeti Ölçeği için ise, sadece güvenilirlik analizleri gerçekleştirilmiştir.

\section{Yetenek Yönetimi Yetkinlikleri Ölçeğine İlişkin Bulgular}

Yetenek Yönetimi Yetkinlikleri Ölçeği'nin yapı geçerliliğ̈ini belirlemek amacıyla Temel Bileşenler Yöntemi ve Oblimin Döndürme Yöntemi kullanılarak açıklayıcı faktör analizi yapılmıştır. Veri setinin faktör analizine uygunluğunu test edebilmek için Kaiser-Meyer-Olkin (KMO) Testi ve Bartlett Küresellik Testi (Bartlett's Test of Sphericity) gerçekleştirilmiştir. KMO değeri 0,50'den fazla ve Bartlett değeri de 0,05 önem derecesinde anlamlı bulunduğundan, veri seti faktör analizine uygun görülmüştür $\left(\mathrm{KMO}=0,981 ; \chi^{2}\right.$ Bartlett test $(903)=18273, \mathrm{p}=0,000)$. 
Yapılan AFA sonucunda Joliffe Kriteri (Kalaycı, 2010: 322) esas alınarak özdeğer istatistiği 0,7'nin üzerinde kalan sayıda faktör elde edilmiştir (5 faktör). Bu 5 faktör toplam varyansın \%75,023'ünü açıklamaktadır. AFA'da ifadelerin bir faktördeki yük değerlerinin en az 0,30 olmasına ve iki faktörde birbirine yakın faktör yükleri alan ifadeler için faktör yükleri arasında en az 0,10 faktör yükü fark olmasına dikkat edilmiştir (Büyüköztürk, 2007). Değişkenin faktörü temsil etme derecesini gösteren faktör yükü büyüklüğünün asgari 0,30 olması gerekmektedir (Gegez, 2007). Bu şekilde ele alındığında koşulları sağlamayan ölçekteki B4, B7, B11, B17, B21, B28 numaralı ifadeler analizden çıkartılmıştır. İlgili ifadeler dışarıda bırakılarak analiz yeniden gerçekleştirildiğinde 37 ifade, 5 faktörlü ve sağlıklı bir yapı oluşturmuştur. İfadelerin faktörlere dağılımına bakıldığında, yetenek yönetimi yetkinliklerini ölçen ölçeğin faktör yapısı 8 boyutlu orijinal ölçekten farklı dağılım göstermiştir. Orijinal ölçekte yer alan 'yetenekli işgörenleri geliştirme' ve 'olumlu ilişkiler kurma ve sürdürme' boyutlarının ifadeleri bu çalışmada 'işgörenleri geliştirme ve onlarla olumlu ilişki kurma' boyutunda; orijinal ölçekte 'yetenek yönetimi zihniyeti sergileme' ve 'yetenekli işgörenleri belirleme ve farklılaştırma' boyutlarının ifadeleri bu çalı̧̧mada 'yetenek yönetimi zihniyeti sergileme ve yetenekli işgörenleri belirleme' boyutunda; orijinal ölçekte 'anlamlı ve iddialı iş sağlama' ve 'adil davranma ve ödüllendirme' boyutlarının ifadeleri bu çalışmada 'anlamlı iş sağlama ve ödüllendirme' boyutunda toplanmıştır. Diğer yandan, 'yeteneği cezbetme ve işe alma' ve 'işgörenlerin iş yaşam dengesini yönetme' boyutları orijinal ölçekle benzer şekilde oluşmuştur. Her bir faktör için faktör yükleri 'işgörenleri geliştirme ve onlarla olumlu ilişki kurma' için 0,342-0,557 aralığında; 'yetenek yönetimi zihniyeti sergileme ve yetenekli işgörenleri belirleme' için 0,440-0,782 aralığında; 'anlamlı iş sağlama ve ödüllendirme' için 0,458-0,789 aralığında; 'yeteneği cezbetme ve işe alma' için 0,435-0,853 aralığında ve 'işgörenlerin iş yaşam dengesini yönetme' için 0,422-0,789 aralığında değişmektedir. Daha sonra, Cronbach $\alpha$ (Cronbach's Alpha) değerlerini kullanarak elde edilen yetenek yönetimi yetkinlikleri faktörlerinin ayrı ayrı ve toplamda güvenilirlik düzeyleri saptanmıştır. 'İşgörenleri geliştirme ve onlarla olumlu ilişki kurma' boyutunun güvenilirliği 0,968; 'yetenek yönetimi zihniyeti sergileme ve yetenekli işgörenleri belirleme' boyutunun güvenilirliği 0,944; 'yeteneği cezbetme ve işe alma' boyutunun güvenilirliği 0,840 ; 'işgörenlerin iş yaşam dengesini yönetme' boyutunun güvenilirliği 0,943 ve 'anlamlı iş sağlama ve ödüllendirme' boyutunun güvenilirliği 0,953 olarak bulunmuştur. Ölçekteki ifadeler toplu güvenilirlik analizine tabi tutulduğunda ise Cronbach $\alpha$ değeri 0,984 gibi yüksek ve kabul edilebilir düzeyde çıkmıştır.

Yetenek Yönetimi Yetkinlikleri Ölçeği için AFA ile elde edilen 5 faktörlü ölçeğin DFA'sı da gerçekleştirilmiştir. DFA'da iyi uyum istatistikleri olarak Uyum İyiliği İndeksi (GFI), Düzeltilmiş Uyum İyiliği İndeksi (AGFI), KiKare İstatistiği $\left(\chi^{2}\right)$, Ki-Kare/serbestlik derecesi $\left(\chi^{2} / \mathrm{sd}\right)$ ve Yaklaşık Hataların Ortalama Karekökü (RMSEA) değerleri kullanılmıştır. Meydan ve Şeşen (2011: 37) kabul edilebilir uyum düzeylerini $\chi^{2} / \mathrm{sd} \leq 5$; GFI $\geq 0,85$; AGFI $\geq 0,85 ;$ RMSEA $\leq 0,08$ olarak ele alınmıştır. İlk elde edilen modelin uyum indeksi sonuçlarına bakıldığında, $\chi^{2} / \mathrm{sd}=3,036(1879,21 / 619), \mathrm{p}=0,000 ; \mathrm{GFI}=0,778 ; \mathrm{AGFI}=0,748$ ve RMSEA=0,074 şeklinde elde edilmiştir. Bu değerlerden $\chi^{2} / \mathrm{sd}$ ve RMSEA değerleri iyi ve kabul edilebilir uyum kriterlerini sağlarken, GFI ve AGFI değerleri iyi ya da kabul edilebilir uyumu sağlamamaktadır. Bir dizi modifikasyon sonrası modelin uyum indeksi sonuçlarına bakıldığında, $\chi^{2} / \mathrm{sd}=2,384$ (1432,57/601); $\mathrm{p}=0,000 ; \mathrm{GFI}=0,829 ; \mathrm{AGFI}=0,802$ ve RMSEA=0,061 şeklinde elde edildiği görülmektedir. Bone vd.'ne (1989) göre, GFI ve AGFI değerlerinin kritik değerlerin çok az altında kalması örneklem büyüklüğü veya modelin karmaşıklığıla ilişkilendirilebilmektedir. Yapılan analizlerde GFI ve AGFI değerlerinin kritik değerlerin az miktar altında çıması bu nedenle olabilir. Sonuç olarak, elde edilen bu uyum indeksleri modelin kabul edilebilir bir uyuma sahip olduğunu ortaya koymaktadır denilebilir.

DFA'sı yapılmış bulunan Yetenek Yönetimi Yetkinlikleri Ölçeği'nin yapı güvenilirliği (construct/composite reliability-CR) analizi ve ortalama açıklanan varyans (AVE) analizi gerçekleştirilmiştir. Bu değerler elde edilirken, elektronik ortamda hesaplamaya olanak sağlayan bir excel makro dosyasından yararlanılmıştır. CR ve AVE hesaplamada yararlanılan ana formüller şu şekildedir (Fornell ve Larcker, 1981):

$\mathrm{CR}=\frac{\left(\sum \lambda_{i}\right)^{2}}{\left(\sum \lambda_{i}\right)^{2}+\sum \operatorname{Var}\left(\varepsilon_{i}\right)} \quad A V E=\frac{\sum \lambda_{i}^{2}}{\sum \lambda_{i}^{2}+\sum_{i} \operatorname{var}\left(\varepsilon_{i}\right)}$

$\lambda$ : madde faktör yükü $\varepsilon$ : gözlenen değişken hata değeri

Yapı güvenilirliği (CR) ve ortalama açıklanan varyans (AVE) hesaplamalarında arzu edilen ilgili faktörün (boyutun) CR değerinin 0,70'den büyük, AVE değerinin 0,50'den büyük ve bununla birlikte CR değerinin 


\section{H. Boz 13/4 (2021) 3236-3264}

AVE'den büyük olmasıdır (Fornell ve Larcker, 1981). Tablo 2'de görüleceği üzere, Yetenek Yönetimi Yetkinlikleri Ölçeği'nin tüm boyutlarının yapı güvenilirliği ve ortalama açıklanan varyans değerleri ilgili koşulları sağlamaktadır. Bu bulgular, Yetenek Yönetimi Yetkinlikleri Ölçeği'nin yakınsama (birleşme) geçerliliğinin sağlandığına ilişkin kanıt oluşturmaktadır.

Tablo 2. Yetenek Yönetimi Yetkinlikleri Ölçeği'nin CR ve AVE Değerleri

\begin{tabular}{|l|c|c|}
\hline \multicolumn{1}{|c|}{ Ölçeğin Boyutları } & CR & AVE \\
\hline İşörenleri geliştirme ve onlarla olumlu ilişki kurma & 0,968 & 0,754 \\
\hline $\begin{array}{l}\text { Yetenek yönetimi zihniyeti sergileme ve yetenekli } \\
\text { işgörenleri belirleme }\end{array}$ & 0,943 & 0,676 \\
\hline Yeteneği cezbetme ve işe alma & 0,835 & 0,561 \\
\hline İşgörenlerin iş yaşam dengesini yönetme & 0,942 & 0,731 \\
\hline Anlamlı iş sağlama ve ödüllendirme & 0,952 & 0,690 \\
\hline
\end{tabular}

Çalışmaya Tutkunluk Ölçeğine İlişkin Bulgular

Çalışmaya tutkunluk ölçeğinin yapı geçerliliğini belirlemek amacıyla Temel Bileşenler Yöntemi ve Oblimin Döndürme Yöntemi kullanılarak AFA yapılmıştır. KMO değeri 0,50'den fazla ve Bartlett değeri de 0,05 önem derecesinde anlamlı bulunduğundan veri seti faktör analizine uygun görülmüştür (KMO $=0,932 ; \chi^{2}$ Bartlett test (136)=3989, p=0,000). AFA sonucunda, özdeğerler esas alınarak özdeğeri 1'in üzerinde kalan sayıda faktör elde edilmiştir (3 faktör). Bu 3 faktör toplam varyansın \%65,192'sini açılamaktadır. Yetenek Yönetimi Yetkinlikleri Ölçeği'ni değerlendirirken göz önünde bulundurulan benzer koşulları sağlamayan bu ölçekteki C60 numaralı ifade analizden çıkartılmıştır. Analiz yeniden gerçekleştirildiğinde, 16 ifade 3 faktörlü ve sağlıklı bir yapı oluşturmuştur. Ölçeğin faktörleri 'adanmışlık', 'yoğunlaşma' ve 'dinçlik' şeklindedir. Bu faktörleşme yapısı orijinal ölçeğin faktörleşme yapısıyla aynıdır, fakat orijinal ölçekte C48 ve C49 numaralı ifadeler dinçlik faktöründe toplanırken bu çalışmada adanmışlık faktöründe toplanmıştır. Her bir faktör için faktör yükleri 'adanmışlık' için 0,520-0,842 aralığında; 'yoğunlaşma' için 0,676-0,818 aralığında ve 'dinçlik' için 0,620-0,885 aralığında değişmektedir. 'Adanmışlık' boyutunun güvenilirliği 0,879 ; 'yoğunlaşma' boyutunun güvenilirliği 0,837 ve 'dinçlik' boyutunun güvenilirliği 0,889 şeklindedir. Ölçekteki ifadeler toplu güvenilirlik analizine tabi tutulduğunda Cronbach $\alpha$ değeri 0,922 gibi yüksek ve kabul edilebilir düzeyde çıkmıştır.

Çalışmaya tutkunluk ölçeğinin DFA sonuçlarına bakıldığında ise, modelin modifikasyona gidilmeksizin kabul edilebilir uyum değerlerine sahip olduğu görülmüştür $\left[\chi^{2} / \mathrm{sd}=3,044(307,467 / 101), \mathrm{p}=0,000\right.$; GFI= 0,902; AGFI=0,868; RMSEA=0,074]. Diğer yandan, Tablo 3'de yer verilen CR ve AVE değerleri Çalışmaya Tutkunluk Ölçeği'nin yakınsama (birleşme) geçerliliğinin sağlandığına kanıt oluşturduğu söylenebilmektedir.

Tablo 3. Çalışmaya Tutkunluk Ölçeği'nin CR ve AVE Değerleri

\begin{tabular}{|l|c|c|}
\hline \multicolumn{1}{|c|}{ Ölçeğin Boyutları } & CR & AVE \\
\hline Adanmışlı & 0,882 & 0,520 \\
\hline Yoğunlaşma & 0,843 & 0,522 \\
\hline Dinçlik & 0,904 & 0,704 \\
\hline
\end{tabular}

İş Tatmini Ölçeğine İlişkin Bulgular

İş tatmini ölçeğinin yapı geçerliliğini belirlemek amacıyla Temel Bileşenler Yöntemi Oblimin Döndürme Yöntemi kullanılarak AFA yapılmıştır. KMO değeri 0,50' den fazla ve Bartlett değeri de 0,05 önem derecesinde anlamlı bulunduğundan veri seti faktör analizine uygun görülmüştür $\left(\mathrm{KMO}=0,946 ; \chi^{2}\right.$ Bartlett test $(190)=5178$, $\mathrm{p}=0,000)$. AFA sonucunda, özdeğerler esas alınarak özdeğeri 1'in üzerinde kalan sayıda faktör elde edilmiştir (2 faktör). Bu 2 faktör toplam varyansın \%59,986'sını açıklamaktadır. E80 numaralı ifadenin ortak varyans değeri 0,50'den düşük olduğu için faktör analizinden çıarılmıştır. Geriye kalan 19 ifade tekrar faktör analizine tabi tutulmuştur. Yetenek Yönetimi Yetkinlikleri Ölçeği'ni değerlendirirken göz önünde bulundurulan benzer koşulları sağlamayan bu ölçekteki E78 ve E79 numaralı ifadeler de analizden çıartılmıştır. Analiz yeniden gerçekleştirildiğinde, 17 ifadeden oluşan 2 faktörlü ve sağlıklı bir yapı oluşturmuştur. İş tatmini ölçeğinin faktörleri 'dışsal iş tatmini' ve 'içsel iş tatmini' şeklindedir. Bu faktörleşme yapısı orijinal ölçeğin faktörleşme yapısıyla aynıdır, fakat orijinal ölçekte E75 ve E81 numaralı ifadeler içsel iş tatmini faktöründe toplanırken, bu çalışmada dişsal iş tatmini faktöründe toplanmıştır. 'Dışsal iş tatmini'nin faktör yükleri 0,514-0,896 
aralığında ve 'içsel iş tatmini'nin faktör yükleri ise 0,479-0,942 aralığında değişmektedir. 'Dışsal iş tatmini' boyutunun güvenilirliği 0,908 ve 'içsel iş tatmini' boyutunun güvenilirliği 0,898 şeklindedir. Ölçekteki ifadeler toplu güvenilirlik analizine tabi tutulduğunda Cronbach $\alpha$ değeri 0,939 gibi yüksek ve kabul edilebilir düzeyde çıkmıştır.

İş tatmini ölçeği için AFA ile elde edilen 2 faktörlü ölçeğin DFA'sı da gerçekleştirilmiştir. İlk elde edilen modelin uyum indeksi sonuçlarına bakıldığında, $\chi^{2} / \mathrm{sd}=7,101$ (837,923/118), p=0,000; GFI=0,788; AGFI= 0,725 ve $\mathrm{RMSEA}=0,128$ şeklinde elde edilmiştir. Bu değerlerden hiç birisi iyi uyum ve kabul edilebilir uyum değerlerini sağlamamaktadır. En iyi model uyumunu sağlamak için modifikasyona gidilmesi sonrası elde edilen modelin uyum indeksi sonuçlarına bakıldığında, $\chi^{2} / \mathrm{sd}=3,743(419,202 / 112), p=0,000$; GFI= 0,884; AGFI= 0,842 ve RMSEA= 0,086 şeklinde gerçekleştiği görülmüştür. Elde edilen sonuçlar, $\chi^{2} /$ sd ve GFI değerlerinin kabul edilebilir uyum değerlerini sağladığını göstermektedir. AGFI değeri de kabul edilebilir düzeyin çok yakınındadır. RMSEA değeri ise, 0,086 ile kabul edilen aralık olan 0,08 ve en üst eşik olan 0,10 ve altı değerler kapsamında yer aldığı için kabul edilebilir uyum için yeterli görülebilmektedir (Hair vd., 1998). Sonuç olarak elde edilen bu uyum indekslerine göre modelin kabul edilebilir uyum değerlerine sahip olduğu söylenebilir. Tablo 4'de yer verilen İş Tatmini Ölçeği'nin CR ve AVE değerlerine bakıldığında ise, ölçeğin yakınsama (birleşme) geçerliliğinin sağlandığı söylenebilmektedir.

Tablo 4. İş Tatmini Ölçeği’nin CR ve AVE Değerleri

\begin{tabular}{|l|c|c|}
\hline \multicolumn{1}{|c|}{ Ölçeğin Boyutları } & CR & AVE \\
\hline Dışsal İs Tatmini & 0,900 & 0,503 \\
\hline$\dot{I}_{\text {çsel İ̧̧ Tatmini }}$ & 0,894 & 0,515 \\
\hline
\end{tabular}

Duygusal Bă̆lılık Ölçeğine İlişkin Bulgular

6 ifadeden oluşan duygusal bağlılık ölçeği tek faktör olarak ele alındığından açıklayıcı ve doğrulayıcı faktör analizi yapılmamıştır. Ölçeğin güvenilirlik düzeyine ilişkin iç tutarlılıklar hesaplanırken Cronbach $\alpha$ değeri kullanılmıştır. Duygusal bağlılık ölçeğinin Cronbach $\alpha$ değeri 0,823 olarak hesaplanmıştır. Bu düzey duygusal bağlılık ölçeğinin kabul edilebilir ve güvenilir bir ölçek olduğunu göstermektedir.

İşten Ayrılma Niyeti Ölçeğine İlişkin Bulgular

4 ifadeden oluşan İşten Ayrılma Niyeti Ölçeği tek faktör olarak ele alındığından açıklayıcı ve doğrulayıcı faktör analizi yapılmamıştır. Ölçeğin güvenilirlik düzeyine ilişkin iç tutarlılıklar hesaplanırken Cronbach $\alpha$ değeri kullanılmıştır. İşten Ayrılma Niyeti Ölçeği'nin Cronbach $\alpha$ değeri 0,882 olarak hesaplanmıştır. Bu düzey İşten Ayrılma Niyeti Ölçeği'nin oldukça güvenilir bir ölçek olduğunu göstermektedir.

\section{Araştırmanın Hipotezlerine İlişkin Bulgular}

Tablo 5 araştırmanın ana değişkenlerinin (yetenek yönetimi yetkinlikleri, duygusal bağlllık, çalışmaya tutkunluk, iş tatmini ve işten ayrılma niyeti) ortalama puanlarını, standart sapmalarını ve birbirleri ile olan korelasyonlarını göstermektedir. Tablodaki sonuçlar işten ayrılma niyetinin diğer bütün araştırma değişkenleri ile negatif ve anlamlı ilişkili olduğuna işaret etmektedir. Bununla birlikte işten ayrılma niyetinin yetenek yönetimi yetkinlikleri $(\mathrm{r}=-0,30)$ ve çalışmaya tutkunluk $(\mathrm{r}=-0,36)$ ile olan korelasyonlarının zayıf düzeyde; buna karşılık duygusal bağll1ık $(\mathrm{r}=-0,53)$ ve iş tatmini $(\mathrm{r}=-0,52)$ ile olan korelasyonlarının ise orta düzeyde olduğu tablodan anlaşılmaktadır. İş tatmini değişkeni duygusal bağlılık $(\mathrm{r}=0,65)$, çalışmaya tutkunluk $(r=0,55)$ ve yetenek yönetimi yetkinlikleri $(r=0,53)$ değişkenleri ile pozitif ve orta düzeyde ilişkilidir. Duygusal bağlılık değişkeni çalışmaya tutkunluk $(\mathrm{r}=0,47)$ ve yetenek yönetimi yetkinlikleri $(\mathrm{r}=0,30)$ değişkenleri ile pozitif ve zayıf düzeyde ilişkilidir. Yetenek yönetimi yetkinlikleri değişkeni ile çalışmaya tutkunluk $(\mathrm{r}=0,46)$ değişkeni ise pozitif ve zayıf düzeyde ilişkilidir. 


\section{H. Boz 13/4 (2021) 3236-3264}

Tablo 5. Ana Değişkenlerin Ortalamaları, Standart Sapmaları ve Aralarındaki Korelasyon Değerleri

\begin{tabular}{|l|c|c|c|c|c|c|}
\hline & Ortalama & $\begin{array}{c}\text { Standart } \\
\text { Sapma }\end{array}$ & 1 & 2 & 3 & 4 \\
\hline $\begin{array}{l}\text { 1. Yetenek Yönetimi } \\
\text { Yetkinlikleri }\end{array}$ & 3,60 & 0,93 & - & & & \\
\hline 2. Çalışmaya Tutkunluk & 3,77 & 0,69 & $0,46^{* *}$ & - & & \\
\hline 3. Duygusal Bağllılık & 3,64 & 0,85 & $0,30^{* *}$ & $0,47^{* *}$ & - & \\
\hline 4. Işs Tatmini & 3,56 & 0,72 & $0,53^{* *}$ & $0,65^{* *}$ & $0,55^{* *}$ & - \\
\hline 5. İșten Ayrılma Niyeti & 2,74 & 1,14 & $-0,30^{* *}$ & $-0,36^{* *}$ & $-0,53^{* *}$ & $-0,52^{* *}$ \\
\hline
\end{tabular}

${ }^{*} \mathrm{p}<0,05 ;{ }^{* *} \mathrm{p}<0,01$

Araştırmanın modeline ilişkin hipotezlerin test edilmesinde yapısal eşitlik modellemesinden (YEM) yararlanılmıştır. Çalışmada YEM ile ilgili analizler için IBM SPSS AMOS 22.0 istatistik paket programı kullanılmıştır. Birçok bilim dalı tarafından kullanılan YEM, belirli bir kurama dayalı olarak gözlenebilen ve gözlenemeyen değişkenlerin nedensel ve ilişkisel bir modelde tanımlanmasına dayanan çok değişkenli bir istatistiksel yöntem olarak bilinmektedir. YEM'i günümüzde ön plana çıkaran belki de en önemli neden gözlenebilen ve gözlenemeyen değişkenler arasındaki doğrudan ve dolaylı etkilerin tek bir modelde test edilebilmesidir. Bu açıdan YEM, aynı anda yapılan birden fazla regresyon analizi olarak değerlendirilebilir (Meydan ve Şeşen, 2011: 5).

Araştırmada YEM ile ölçülecek temel modele ve modele ilişkin hipotezlere önceki bölümlerde yer verilmiştir. Araştırma modeli yetenek yönetimi yetkinlikleri ile işten ayrılma niyeti ilişkisinde çalışmaya tutkunluk, duygusal bağlılık ve iş tatmininin aracılık etkilerine odaklanmaktadır. Modelin yol diyagramı çizilirken yapılan faktör analizlerinde çıkarılan ifadeler göz önünde bulundurulmuştur. Araştırmanın gözlenen değişkenleri ve gizil (örtük) değişkenleri Tablo 6'da yer almaktadır.

Tablo 6. Araştırma Modelinin Gözlenen ve Gizil Değişkenleri

\begin{tabular}{|c|c|}
\hline Gizil Değişkenler & Gözlenen Değişkenler \\
\hline \multirow{5}{*}{$\begin{array}{l}\text { Yetenek Yönetimi } \\
\text { Yetkinlikleri } \\
\text { (YYY) }\end{array}$} & İşgörenleri geliştirme ve onlarla olumlu ilişki kurma (GELISOLUMLUILIS) \\
\hline & Yetenek yönetimi zihniyeti sergileme ve yetenekli işgörenleri belirleme (YYZIHBEL) \\
\hline & Yeteneği cezbetme ve işe alma (CEZBETME) \\
\hline & İşgörenlerin iş yaşam dengesini yönetme (ISYASAM) \\
\hline & Anlamlı iş sağlama ve ödüllendirme (ANLAMISODUL) \\
\hline \multirow{3}{*}{$\begin{array}{l}\text { Çalışmaya } \\
\text { Tutkunluk } \\
\text { (CALTUT) }\end{array}$} & Adanmışlık (ADANMISLIK) \\
\hline & Yoğunlaşma (YOGUNLASMA) \\
\hline & Dinçlik (DINCLIK) \\
\hline \multirow{2}{*}{$\begin{array}{l}\text { İş Tatmini } \\
\text { (ISTAT) }\end{array}$} & Dişsal İş Tatmini (DISSAL) \\
\hline & İçsel İş Tatmini (ICSEL) \\
\hline \multirow{6}{*}{$\begin{array}{l}\text { Duygusal Bağll1ık } \\
\text { (DUYBAG) }\end{array}$} & Kariyerimin geri kalanını bu işletmede geçirmekten mutlu olurum. (D61) \\
\hline & Çalıştığım işletmenin sorunlarını kendi sorunlarım gibi hissediyorum. (D62) \\
\hline & Bu işletmede kendimi “ailenin bir parçası” olarak hissetmiyorum. (D63) \\
\hline & Çalıştı̆̆ım işletmeye karşı duygusal bir bağ hissetmiyorum. (D64) \\
\hline & Çalıştığım işletmeden, dışarıdaki insanlara gururla bahsediyorum. (D65) \\
\hline & Çalıştığım işletmeye karşı güçlü bir aidiyet duygusu hissetmiyorum. (D66) \\
\hline \multirow{4}{*}{$\begin{array}{c}\text { İşten Ayrılma } \\
\text { Niyeti } \\
\text { (IAN) }\end{array}$} & Daha iyi bir alternatifim olsa bu işten ayrılmayı düşünürüm. (F87) \\
\hline & Mümkün olsa işten ayrılmayı düşünürdüm. (F88) \\
\hline & Daha iyi bir alternatif olsa işten ayrılırdım. (F89) \\
\hline & Başka bir yerde iş arıyorum. (F90) \\
\hline
\end{tabular}


Hipotez testleri kapsamında ilk olarak yöneticilerin yetenek yönetimi yetkinliklerinin yetenekli işgörenlerin işten ayrılma niyetine doğrudan etkisini vurgulayan 'Hipotez 1: Yetenek yönetimi yetkinliklerinin işten ayrılma niyeti üzerinde doğrudan negatif bir etkisi vardır.' hipotezi yapısal eşitlik modellemesi yardımıyla test edilmiştir. Tablo 6 ' da yer alan gözlenen değişkenler ve gizil değişkenler kullanılarak yöneticilerin yetenek yönetimi yetkinliklerinin yetenekli işgörenlerin işten ayrılma niyetine doğrudan etkisini (YYY $\rightarrow$ IAN) gösteren yol diyagramı çizilmiştir. Modelin uyum indeksi değerleri incelenirken Ki-kare/serbestlik derecesi $\left(\chi^{2} / \mathrm{sd}\right)$, Tucker-Lewis İndeksi (TLI), Karşılaştırmalı Uyum İndeksi (CFI) ve Kestirim Hatası Kareler Ortalaması (RMSEA) uyum iyiliği değerleri dikkate alınmıştır. Meydan ve Şeşen'e (2011: 37) göre kabul edilebilir uyum düzeyleri $\chi^{2} / \mathrm{sd} \leq 5$; TLI $\geq 0,90$; CFI $\geq 0,95$; RMSEA $\leq 0,08$ şeklindedir. İlk modelin uyum indeksi sonuçlarına bakıldığında $\chi^{2} / \mathrm{sd}=6,485(168,618 / 26), \mathrm{p}=0,000 ; \mathrm{TLI}=0,938 ; \mathrm{CFI}=0,955$ ve RMSEA=0,121 şeklinde çıktı̆̆ 1 görülmektedir. Bu değerler kabul edilebilir uyum değerlerini karşılamamaktadır. Bundan dolayı, model üzerinde modifikasyona gidildiğinde uyum değerleri $\chi^{2} / \mathrm{sd}=4,556(113,912 / 25), \mathrm{p}=0,000 ; \mathrm{TLI}=0,960 ; \mathrm{CFI}=0,972$ ve RMSEA=0,097 şeklinde bulunmuştur. RMSEA dışındaki değerler modifikasyonlu modelde kabul edilebilir düzeyleri karşılamaktadır. RMSEA değeri ise, 0,097 ile kabul edilen aralık olan 0,08 ve en üst eşik olan 0,10 ve altı değerler kapsamında yer aldığı için kabul edilebilir uyum için yeterli görülebilmektedir (Hair vd., 1998). $\mathrm{Bu}$ değerler, modelin modifikasyonlu haliyle daha iyi ve kabul edilebilir uyuma sahip olduğunu göstermektedir.

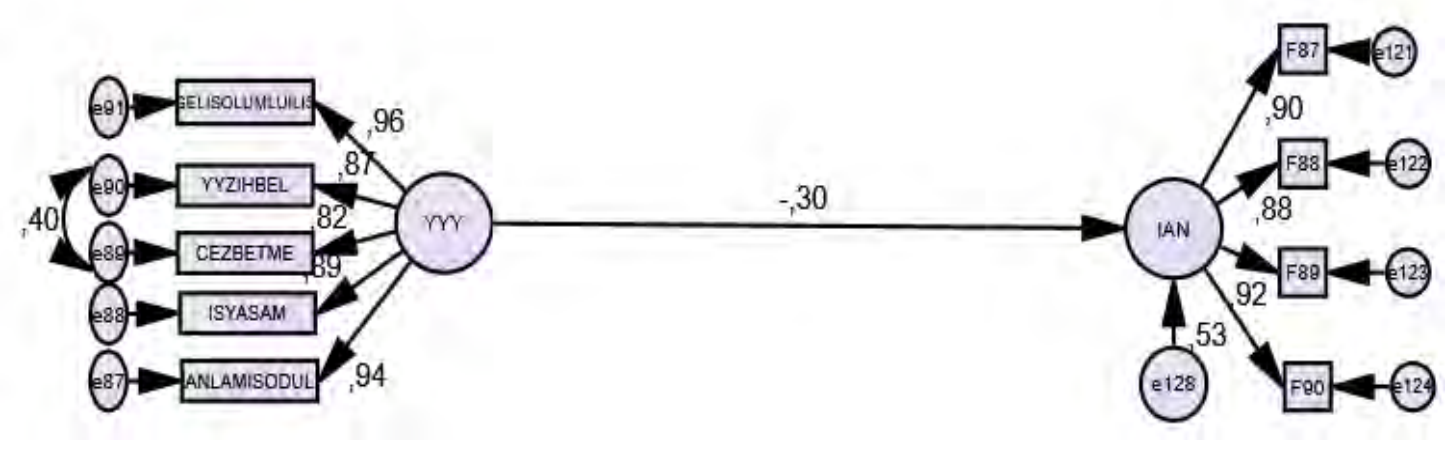

Şekil 2. Yetenek Yönetimi Yetkinliklerinin İşten Ayrılma Niyetine Doğrudan Etkisi

Şekil 2'de son haline yer verilen modele göre yöneticilerin yetenek yönetimi yetkinliklerinin, yetenekli işgörenlerin işten ayrılma niyetine doğrudan anlamlı ve negatif etkisinin (YYY $\rightarrow$ IAN) olduğu bulunmuştur $(c=-0,30 ; p<0,01)$. Yani, 'Hipotez 1: Yetenek yönetimi yetkinliklerinin işten ayrılma niyeti üzerinde doğrudan negatif bir etkisi vardır.' hipotezi kabul edilmiştir.

Hipotez 2, Hipotez 3 ve Hipotez 4 hipotezleri aracı etkiye işaret eden hipotezlerdir. Araştırma modelinde aracı etkiden söz edebilmek için sağlanması gereken bazı koşullar söz konusudur. Baron ve Kenny'e (1986: 11751177) göre, bu koşullar aşağıdaki şekilde ele alınabilir:

- Bağımsız değişken olarak ele alınan değişkenin, bağımlı değişken üzerindeki etkisinin anlamlı olması gerekir.

- Bağımsız değişkenin, aracı olduğu düşünülen değişken üzerindeki etkisinin anlamlı olması gerekmektedir.

- Aracı etkisi olduğu düşünülen değişkenin bağımlı değişken üzerindeki etkisinin anlamlı olması gerekmektedir.

- Bağımsız değiş̧kenler ile aracı olduğu düşünülen değişkenler arasındaki ve aracı değişkenler ile bağımlı değişkenler arasındaki etkiler kontrol altında tutulduğunda, bağımsız değişkenin bağımlı değişken üzerindeki etkisi anlamsızlaşıyor ya da etkinin anlamlılı̆̆ı düşüyorsa, ilgili değişkenin aracılık etkisi olduğundan söz edilir. Eğer bağımsız değişkenin bağımlı değişkene etkisi anlamsız hale geliyorsa ilgili aracılık etkisinin tam aracılık etkisi olduğundan, eğer bağımsız değişkenin bağımlı değişkene etkisinin düzeyi düşüyor, ancak etki anlamsız hale gelmiyorsa kısmi aracılık etkisinin olduğundan söz edilmektedir.

Aracılık etkisi incelenirken X (bağımsız değişken), Y (bağımlı değişken) ve M (aracı değişken) olarak ele alındığında; doğrudan etki $X \rightarrow Y$ olarak gösterilebilirken, aracılık etkisi $X \rightarrow M \rightarrow Y$ şeklinde gösterilebilir. Bu ilişkiler bir bütün olarak Şekil 3 ve Şekil 4'teki haliyle gösterilebilir. 


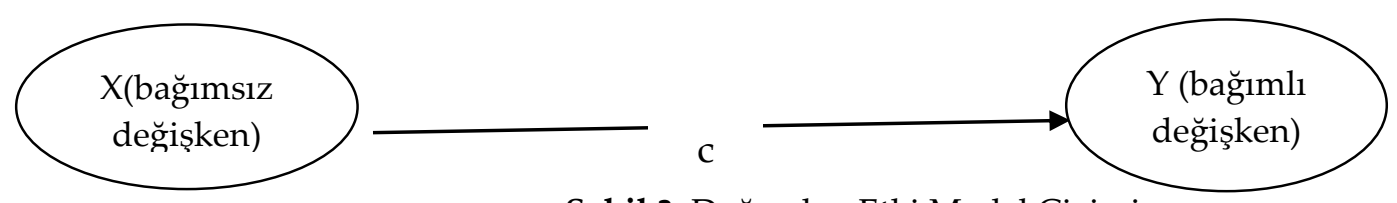

Şekil 3. Doğrudan Etki Model Çizimi

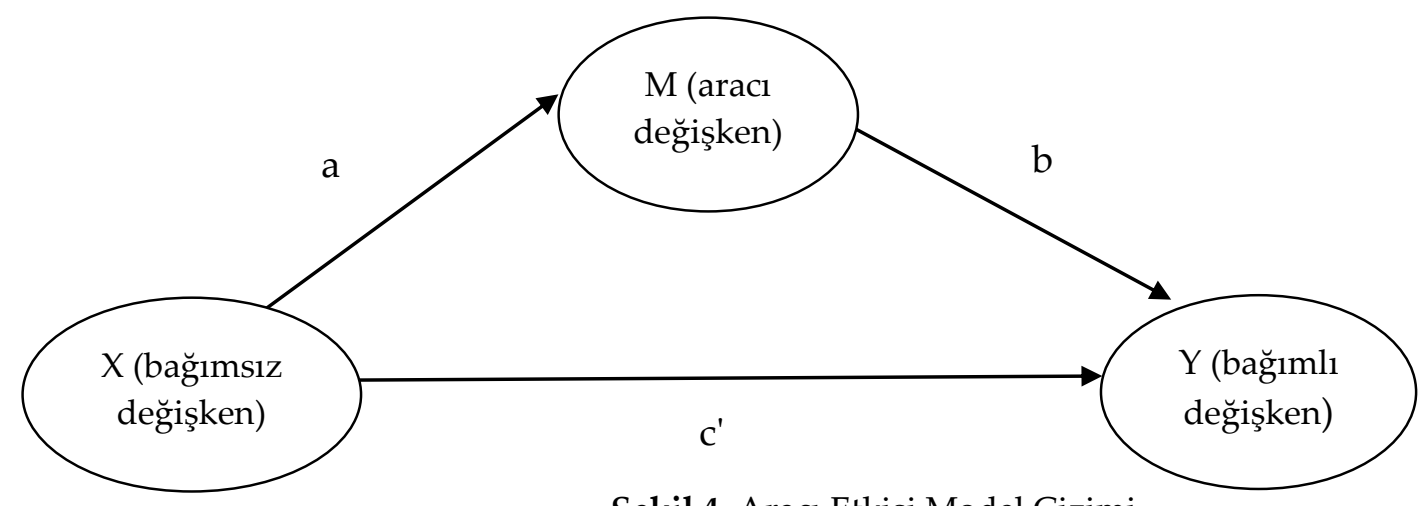

Şekil 4. Aracı Etkisi Model Çizimi

Şekil 3' de yer alan ' $c$ ' değeri bağımsız değişkenin bağımlı değişken üzerindeki doğrudan etki derecesine işaret etmektedir. Şekil 4'de gösterilen 'a' değeri bağımsız değişkenin aracı değişken üzerindeki doğrudan etki derecesine, ' $b$ ' değeri aracı değişkenin bağımlı değişken üzerindeki doğrudan etki derecesine ve ' $c$ ' değeri ise, bağımsız değişken ile aracı değişken arasındaki ilişki ve aracı değişken ile bağımlı değişken arasındaki ilişki kontrol altında tutulduğunda bağımsız değişkenin bağımlı değişken üzerindeki etki derecesine işaret etmektedir. Burada yer alan c, a, b ve c' yapısal eşitlik modellemesi yoluyla elde edilen standardize edilmiş regresyon değerlerini temsil etmektedir.

Baron ve Kenny'e (1986) göre, aracılık etkisinin ilk koşulu olan bağımsız değişkenin (yetenek yönetimi yetkinliklerinin) bağımlı değişken (işten ayrılma niyeti) üzerindeki doğrudan etkisinin anlamlı olduğu 'Hipotez 1: Yetenek yönetimi yetkinliklerinin işten ayrılma niyeti üzerinde doğrudan negatif bir etkisi vardır.' hipotezinin kabulüyle sağlanmıştır.

Aracı etkili hipotezlerin araştırma modeli kapsamında test edilebilmesi amaciyla Tablo 6'da yer alan gözlenen değişkenler ve gizil değişkenler kullanılarak ana modelin yol diyagramı çizilmiştir. Modifikasyonsuz ilk modelin uyum değerlerinin $\chi^{2} / \mathrm{sd}=8,728(1422,71 / 163), \mathrm{p}=0,000$; TLI=0,758; CFI=0,793 ve RMSEA=0,144 şeklinde çıktığı görülmektedir. Modele ilişkin daha iyi uyum değerleri sağlamak için model modifikasyonlarına gidildiğinde, son durumda Şekil 5'de yer alan model elde edilmiştir. Modifikasyonlu modelin uyum değerlerine bakıldığında, $\chi^{2} / \mathrm{sd}=4,492$ (691,750/154), $\mathrm{p}=0,000$; TLI=0,904; CFI=0,911 ve RMSEA = 0,096 şeklinde çıktığ 1 görülmektedir. $\chi^{2} / \mathrm{sd}$ ve TLI değerleri kabul edilebilir uyum değerlerini karşılamaktadır. Diğer yandan, RMSEA değeri ise, 0,096 ile kabul edilen aralık olan 0,08 ve en üst eşik olan 0,10 ve altı değerler kapsamında yer aldığ için kabul edilebilir uyum için yeterli görülebilmektedir (Hair vd., 1998). CFI değeri ise 0,911 düzeyinde çıkmış olup kabul edilebilir uyum değerine yakındır. Bu bağlamda ele alındığında modelin bu şekliyle kabul edilebilir uyum değerlerine sahip olduğu söylenebilir. 


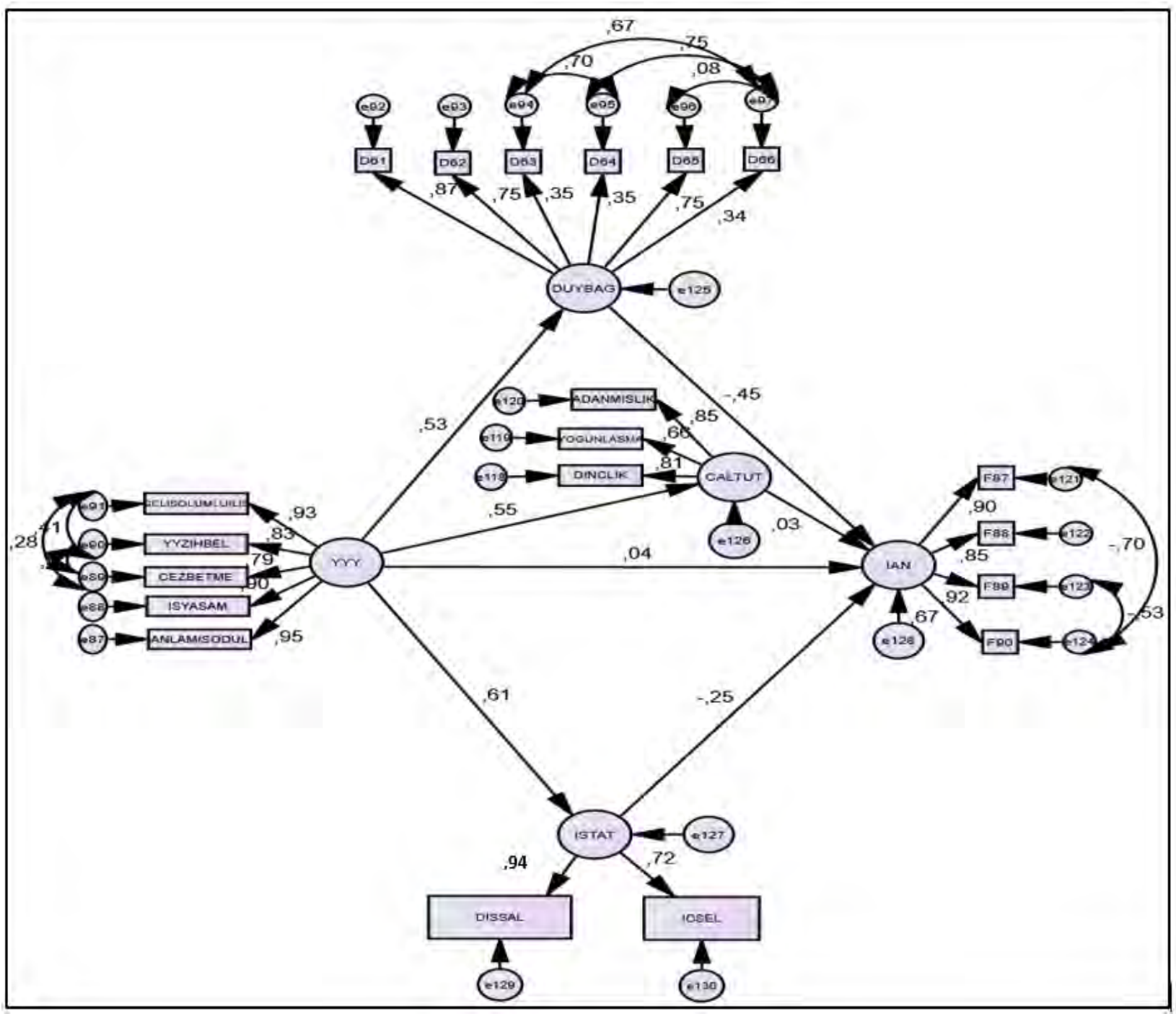

Şekil 5. Araştırma Modeli İçin Yol Diyagramı

Şekil 5'de modelin son haliyle yer verilen değerler, standardize edilmiş regresyon değerlerini göstermektedir. Model üzerinde yer alan bu değerler hipotez testi sonuçlarının anlaşılmasına olanak sağlamaktadır.

Şekil 2'de yer alan modele göre yetenek yönetimi yetkinliklerinin işten ayrılma niyetine doğrudan etkisinin $(Y Y Y \rightarrow$ IAN) anlamlı olduğu bulunmuştur (c=-0,30; $<<0,01)$. Baron ve Kenny'e (1986) göre söz konusu bu anlamlı etki aracı değişkenler (çalışmaya tutkunluk, duygusal bağlllık, iş tatmini) devreye girdiğinde, anlamsızlaşıyorsa ya da etki düzeyi azalıyorsa, bu durum ilgili aracı değişkenin aracılık etkisinin olduğunu göstermektedir. Bu bağlamda Şekil 5'de yer verilen ana modele dayalı olarak Hipotez 2, Hipotez 3 ve Hipotez 4 hipotezlerinin testine ilişkin analizler aşağıda sırasıyla ele alınmaktadır.

'Hipotez 2: Duygusal bağlılık yetenek yönetimi yetkinlikleri ile işten ayrılma niyeti arasında aracılık etkisine sahiptir.' hipotezi kabul edilmiştir. Şekil 2 ve Şekil 5 birlikte değerlendirildiğinde görüleceği üzere, Baron ve Kenny'e (1986) göre, duygusal bağlllığın yetenek yönetimi yetkinlikleri ile işten ayrılma niyeti arasında aracılık etkisi olduğuna ilişkin bütün koşullar sağlanmıştır. Şekil 5'e göre, yetenek yönetimi yetkinliklerinin duygusal bağlılık üzerindeki doğrudan etkisi (YYY $\rightarrow$ DUYBAG) anlamlıdır $(a=0,53 ; p<0,01)$. Duygusal bağlılığın işten ayrılma niyeti üzerindeki doğrudan etkisi (DUYBAG $\rightarrow$ IAN) anlamlıdır $(b=-0,45 ; p<0,01)$. Son olarak bağımsız değişken (yetenek yönetimi yetkinlikleri) ile aracı değişken (duygusal bağlılık) arasındaki ve aracı değişken (duygusal bağlılık) ile bağımlı değişken (işten ayrılma niyeti) arasındaki etkiler kontrol altında tutulduğunda, bağımsız değişkenin (yetenek yönetimi yetkinlikleri) bağımlı değişken (işten ayrılma niyeti) üzerindeki etkisi anlamsız hale gelmiştir $\left(c^{\prime}=0,04 ; p>0,05\right)$. Bu durum duygusal bağlllı̆̆ın yetenek yönetimi yetkinlikleri ile işten ayrılma niyeti arasında tam aracılık rolü üstlendiğini göstermektedir. 
‘Hipotez 3: Çalışmaya tutkunluk yetenek yönetimi yetkinlikleri ile işten ayrılma niyeti arasında aracılık etkisine sahiptir.' hipotezi reddedilmiştir. Şekil 2 ve Şekil 5 birlikte değerlendirildiğinde görüleceği üzere, Baron ve Kenny'e (1986) göre, çalışmaya tutkunluğun yetenek yönetimi yetkinlikleri ile işten ayrılma niyeti arasında aracılık etkisi olduğuna ilişkin bütün koşullar sağlanamamıştır. Şekil 5'e göre, yetenek yönetimi yetkinliklerinin çalışmaya tutkunluk üzerindeki doğrudan etkisi (YYY $\rightarrow$ CALTUT) anlamlıdır ( $\mathrm{a}=0,55$; $\mathrm{p}<0,01)$. Ancak çalışmaya tutkunluğun işten ayrılma niyeti üzerindeki doğrudan etkisi (CALTUT $\rightarrow$ IAN) anlamlı değildir $(b=0,03 ; p>0,05)$. Bu durum son koşula bakmaya gerek kalmaksızın, çalışmaya tutkunluğun yetenek yönetimi yetkinlikleri ile işten ayrılma niyeti arasında aracılık rolü üstlenmediğini göstermektedir.

'Hipotez 4: İş tatmini yetenek yönetimi yetkinlikleri ile işten ayrılma niyeti arasında aracılık etkisine sahiptir.' hipotezi kabul edilmiştir. Şekil 2 ve Şekil 5 birlikte değerlendirildiğinde görüleceği üzere, Baron ve Kenny'e (1986) göre iş tatmininin yetenek yönetimi yetkinlikleri ile işten ayrılma niyeti arasında aracılık etkisi olduğuna ilişkin bütün koşullar sağlanmıştır. Şekil 5'e göre, yetenek yönetimi yetkinliklerinin iş tatmini üzerindeki doğrudan etkisi (YYY $\rightarrow$ ISTAT) anlamlıdır $(a=0,61 ; p<0,01)$. İş tatmininin işten ayrılma niyeti üzerindeki doğrudan etkisi (ISTAT $\rightarrow$ IAN) anlamlıdır $(b=-0,25 ; p<0,01)$. Son olarak bağımsız değişken (yetenek yönetimi yetkinlikleri) ile aracı değişken (iş tatmini) arasındaki ve aracı değişken (iş tatmini) ile bağımlı değişken (işten ayrılma niyeti) arasındaki etkiler kontrol altında tutulduğunda, bağımsız değişkenin (yetenek yönetimi yetkinlikleri) bağımlı değişken (işten ayrılma niyeti) üzerindeki etkisi anlamsız hale gelmiştir $\left(c^{\prime}=0,04 ; p>0,05\right)$. Bu durum iş tatmininin yetenek yönetimi yetkinlikleri ile işten ayrılma niyeti arasında tam aracılık rolü üstlendiğini göstermektedir.

\section{Sonuç ve Tartışma}

Rekabette yaşanan hızlı gelişmeler, farklı alanlarda faaliyet gösteren işletmeleri ayakta kalma konusunda zorlamaktadır. İşletmelerin yoğun rekabet koşullarında varlık gösterebilmeleri sahip oldukları insan kaynağından ve insan kaynağının niteliğinden önemli ölçüde etkilenmektedir. İnsan kaynağının rekabet açısından taşıdığı önemin bilincinde olan işletmeler, özellikle son dönemde yetenek yönetimi konusuna yoğun ilgi göstermektedir. Hızlı değişim gösteren rekabet koşullarında fark yaratma potansiyeli olan yetenekli işgörenlerin işletmeye çekilmesi, geliştirilmesi ve elde tutulması konusunda kritik işlevler üstlenen yetenek yönetimi, insan kaynakları alanında önemli bir zihniyet değişimine işaret etmektedir.

İşletmelerde yetenek yönetimi uygulamaları genel itibariyle insan kaynakları uygulamaları üzerine kuruludur, fakat bu uygulamaların yürütülmesi sorumluluğu sadece insan kaynakları bölümünde değildir. Bu bağlamda, yetenek yönetimi uygulamalarının hayata geçirilmesi ve devamlılığının sağlanması başta tepe yönetim olmak üzere, orta kademe yöneticiler ve insan kaynakları bölümünün üstleneceği sorumluluklar ile olanaklı olacaktır. Özellikle yetenek yönetiminin uygulanması sürecinde, farklı düzeylerdeki yöneticilerin yetenekleri yönetme konusunda sahip oldukları yetkinlikleri mevcut yetenekli işgörenlerin gelişimi ve elde tutulması, potansiyel işgörenlerin ise cezbedilerek işletmeye kazandırılmasında kritik öneme sahiptir. İşletmelerde yöneticilerin sahip olduğu yetenek yönetimi yetkinliklerinin kendilerine bağlı çalışan işgörenlerin işletmeden ayrılma niyetlerine etkisini ve bu ilişkide işgörenlerin duygusal bağllıklarının, çalışmaya tutkunluklarının ve iş tatminlerinin aracılık rolü üstlenip üstlenmediklerini bankacılık sektöründe çalışan yetenekli işgörenler özelinde ve onların algılarına dayalı olarak araştıran bu çalışmada önemli bulgulara ulaşılmıştır.

Yetenek yönetimi uygulamaları ile öne çıkan beş farklı bankanın Antalya ili genelindeki şubelerinde çalışan ve yetenekli işgören olarak değerlendirilen 376 işgörenden toplanan verilerin yapısal eşitlik modellemesi yardımıyla gerçekleştirilen hipotez testlerinin sonuçları, yöneticilerin sahip olduğu yetenek yönetimi yetkinlikleri bütününün, yetenekli işgörenlerin işten ayrılma niyetleri üzerinde doğrudan negatif bir etkisinin olduğunu göstermiştir. Yani yetenekli işgörenlerin algısına dayalı olarak, yöneticilerin sahip olduğu yetenek yönetimi yetkinlikleri doğrudan işgörenlerin işten ayrılma niyeti taşımaları ve haliyle işten ayrılmaları üzerinde etkili görülmektedir. Bu durum alanyazındaki çalışmalarla tutarlı görülmektedir. Daha önce yapılmış çalışmalar incelendiğinde, boyutlar halinde yetenek yönetimi yetkinliklerini ele alan Darvish (2012), her bir yetenek yönetimi yetkinliği ile işgörenin işten ayrılma niyeti arasında negatif yönlü ve anlamlı ilişki saptamıştır. Sivanesan (2014) ise yetenek yönetimi yetkinlikleri arasında geçen olumlu ilişkiler kurma ve geliştirme, anlamlı ve iddialı iş sağlama ve adil davranma ve ödüllendirme boyutları ile işten ayrılma niyeti arasında anlamlı ve negatif yönlü ilişkiler bulmuştur. Barkhuizen vd. (2015) ve Du Plessis vd. (2015) de 


\section{H. Boz 13/4 (2021) 3236-3264}

yetenek yönetimi ile işten ayrılma niyeti arasında negatif yönlü ve anlamlı ilişki saptamıştır. Diğer yandan, aracı değişkenler kullanıldığında yöneticilerin yetenek yönetimi yetkinliklerinin yetenekli işgörenlerin işten ayrılma niyeti üzerindeki etkisinin ortadan kalktığı görülmüştür. Buna benzer nitelikte bir sonuç Hoogervorst'un (2009) çalışmasında ortaya çıkmıştır. Hoogervorst (2009) yetenek yönetimi uygulamalarının işten ayrılma niyeti üzerindeki etkisini ele aldığı çalışmada, psikolojik sözleşmenin bu ilişkide aracılık rolü üstlenip üstlenmediğini de araştırmıştır. Çalışmada yetenek yönetimi uygulamalarının yetenekli işgörenlerini işten ayrılma niyetleri üzerinde doğrudan anlamlı etkisinin olduğunu, ancak psikolojik sözleşmenin aracılık etmesiyle, yetenek yönetimi uygulamalarının işten ayrılma niyeti üzerindeki doğrudan etkisinin anlamsız hale geldiğini, yetenek yönetimi uygulamalarının işgörenin işten ayrılma niyetini psikolojik sözleşme vasıtasıyla açıkladığını tespit etmiştir.

Araştırma sonuçları yöneticilerin yetenek yönetimi yetkinliklerinin, yetenekli işgörenlerin işletmeye karşı duygusal bağlllıkları üzerinde pozitif yönlü etkiye sahip olduğunu göstermiştir. Bu sonucun alanyazındaki diğer çalışmalarla tutarlı olduğunu söylemek yanlış olmayacaktır. Alanyazındaki bazı çalışmalar (Serim Bahadınlı, 2013; Ping, 2011) yetenek yönetimi uygulamalarının duygusal bağlllığı da içine alan örgütsel bağlılık üzerinde pozitif ve anlamlı etkisini ortaya koyarken; bazı çalışmalar (Chami-Malaeb ve Garavan, 2013) ise yetenek yönetiminin duygusal bağlllık üzerindeki doğrudan pozitif ve anlamlı etkisini saptamıştır. İşletmelerin yetenekli işgörenlerine yönelik gerçekleştirdiği birtakım cezbetmeye, işe almaya, geliştirmeye ve elde tutmaya yönelik uygulamalar bireylerin çalıştıkları işletmeye duygusal açıdan bağlanmaları üzerinde etkili olabilmektedir. Yetenekli işgörenlerin duygusal bağlllıklarının, onların işten ayrılma niyetlerini negatif yönlü ve anlamlı bir biçimde etkilediği de bu araştırmanın sonuçları ile ortaya konulmuştur. Bu bulgu genel anlamda örgütsel bağlllığın işgörenlerin işten ayrılma niyetini negatif ve anlamlı biçimde etkilediğini ifade eden çalışmalar ile (Meyer vd., 2002; Elangovan, 2001; Griffeth vd., 2000; Arnold ve Feldman, 1982) tutarlıdır. Özellikle örgüte duygusal bağlılık çerçevesinde ele alındığında, alanyazında bu araştırmaya benzer biçimde duygusal bağlılığın işten ayrılma niyetinin negatif yönlü ve anlamlı tahmincisi olduğunu gösteren çok sayıda çalışma sözkonusudur (Yasmin ve Marzuki, 2015; Oehley, 2007; Çakar ve Ceylan, 2005; Meyer vd., 2002; Wasti, 2002).

Araştırmadan elde edilen, ilgi çeken sonuçlardan birisi işgörenlerin duygusal bağl1lıklarının, yöneticilerin sahip olduğu yetenek yönetimi yetkinlikleri ile yetenekli işgörenlerin işten ayrılma niyetleri arasında tam aracı rolü üstlenmesidir. Kısaca ifade etmek gerekirse, yöneticilerinin yetenek yönetimi yetkinliklerinin yüksek olduğu algısıyla, örgüte duygusal olarak bağlanan yetenekli işgörenler bunun etkisiyle işletmeden ayrılma niyetinden uzaklaşmaktadır. Alanyazında duygusal bağlılığın bu bağlamda aracılık etkisine dikkat çeken doğrudan bir çalışmaya rastlanılmamıştır, ancak Chami-Malaeb ve Garavan (2013) yaptıkları araştırmada işletmenin yetenek geliştirme uygulamaları ile işgörenin işletmede kalma niyeti arasında duygusal bağlılığın kısmi aracılık rolü üstlendiğini bulgulamıştır.

Son dönemde pozitif psikolojinin ve pozitif örgütsel davranışın etkisiyle tartışılmaya başlanan iş yaşamındaki önemli konulardan birisi çalışmaya tutkunluktur. Çalışmaya tutkunluk, işgören tutkunluğunun örgütsel tutkunluk ile birlikte iki boyutundan birisidir. Araştırma değişkenleri arasında ele alınan çalışmaya tutkunluğun yetenek yönetimi uygulamalarından etkilendiği bulunmuştur. Yetenekli işgörenlerin değerlendirmelerine dayalı olarak, yöneticilerinin sahip olduğu yetenek yönetimi yetkinliklerinin, yetenekli işgörenlerin çalışmaya tutkunlukları üzerinde pozitif ve anlamlı bir etkisinin olduğu tespit edilmiştir. Alanyazın incelendiğinde Alias vd. (2014) ve Aljunaibi (2014) çalışmaya tutkunluğu da içine alan işgören tutkunluğunun yetenek yönetimi uygulamaları ile pozitif yönlü ve anlamlı ilişkisinin olduğunu ortaya koymuşlardır. Barkhuizen vd. (2014) yaptığı çalışmada yetenek yönetimi uygulamaları ile çalışmaya tutkunluk arasında pozitif ve anlamlı ilişki saptamıştır. Bu açıdan bakıldığında, elde edilen sonuçların alanyazınla tutarlı olduğu söylenebilir. Diğer yandan, araştırma sonuçları yetenekli işgörenlerin çalışma tutkunluklarının, onların işten ayrılma niyeti üzerinde doğrudan negatif yönlü ve anlamlı etkisinin olduğuna işaret eden görüşü desteklememiştir. Alanyazına bakıldığında genellikle çalışmaya tutkunluk (ve çalışmaya tutkunluğu içine alan işgören tutkunluğu) ile işten ayrılma niyeti arasında negatif yönlü ve anlamlı ilişkilerin olduğu bulgulanmıştır (El Badawy ve Bassiouny, 2014; Alarcon ve Edwards, 2011; Bal, 2008; Koyuncu vd., 2006). Bu açıdan değerlendirildiğinde, elde edilen sonucun alanyazındaki diğer çalışmalarla örtüşmediği söylenebilir. Burada şu önemli hususa dikkat çekilmesi anlamlı görülmektedir. Bilindiği üzere, çalışmaya tutkunluk örgütsel bağlılıktan farklı bir kavramdır. Örgütsel bağlılı̆̆ı yüksek olan bireyler örgütün amaç ve 


\section{H. Boz 13/4 (2021) 3236-3264}

değerlerini benimsemekte, örgütte kalabilmek adına çaba sergilemekte ve örgütün parçası olmayı sürdürebilme arzusu taşımaktadır. Çalışmaya ve işlerine tutkun olan bireyler örgüte bağlılık duymayabilir ya da tam tersi örgütsel bağlılıkları yüksek olmakla birlikte bireyler çalışmaya tutkun olmayabilir (Roberts ve O’Davenport, 2002). Bu yönden ele alındığında, elde edilen işgörenlerin çalışmaya tutkunluğunun, onların işten ayrılma niyeti üzerinde anlamlı bir etkisinin olmadığı sonucu daha anlamlı hale gelebilecektir. Diğer yandan, araştırmada yetenekli işgörenlerin çalışmaya tutkunluklarının, yöneticilerin yetenek yönetimi yetkinlikleri ile yetenekli işgörenlerin işten ayrılma niyetleri arasında aracılık rolü üstlendiği yönündeki hipotez reddedilmiştir. Alanyazına bakıldığında çalışmaya tutkunluğun yetenek yönetimi ile işten ayrılma niyeti arasında aracılık etkisine dikkat çeken çalışma olmamakla birlikte, Alias vd. (2014) çalışmaya tutkunluğu içine alan işgören tutkunluğunun yetenek yönetimi ile işgörenin elde tutulması arasında aracıllk etkisi olduğunu tespit etmiştir. Bu açıdan değerlendirildiğinde çalışmaya tutkunluğun aracılık etkisine ilişkin elde edilen sonucun alanyazınla örtüşmediği söylenebilir. Bu şekilde bir sonucun elde edilmesi, test edilen ana model bağlamında çok sayıda değişkenin ilişkisinin aynı anda ele alınmasından ileri gelebileceği düşünülmektedir.

Araştırma sonuçları, yetenek yönetimine ilişkin uygulamaların yetenekli işgörenlerin iş tatminine etkisi ile ilgili olarak da değerli bulgular sunmaktadır. Araştırma sonuçlarına göre, yetenekli işgörenlerin algılarına dayalı olarak, yöneticilerin sahip olduğu yetenek yönetimi yetkinlikleri, iş tatminini pozitif yönde ve anlamlı biçimde etkilemektedir. Bu durum alanyazındaki daha önce yapılan çalışmaların sonuçları ile tutarlı bulunmuştur (Hamidi vd., 2014; Serim Bahadınlı, 2013; Tanton, 2007). Yetenekli işgörenlerin iş tatminin, onların işten ayrılma niyeti üzerinde doğrudan negatif yönlü ve anlamlı etkisininin olduğu bulunmuş olup, bu durum alanyazında ortaya konulan çoğu çalışmayla (Sökmen ve Mete, 2015; Poyraz ve Kama, 2008; Çekmecelioğlu, 2005; Rosser, 2004; Shore ve Martin, 1989) tutarlılık göstermektedir. Bunun yanında yetenekli işgörenlerin iş tatmininin, yöneticilerin yetenek yönetimi yetkinlikleri ile işgörenlerin işten ayrılma niyeti arasında tam aracılık rolü üstlendiği sonucuna da ulaşılmıştır. Öyle ki, yöneticilerinin yetenek yönetimi yetkinlik düzeylerinin yüksekliği sayesinde iş tatmini düzeyleri yükselen işgörenlerin, işten ayrılma niyetleri anlamlı biçimde düşmektedir. Alanyazında bu aracılık etkisine dikkat çeken Tanton'un (2007) vaka analizine dayalı çalışması ile bu çalışmanın tutarlı olduğu görülmüştür.

Günümüzde gerek ülkemizde gerekse dünyada ülke ekonomilerinde önde gelen sorunlardan birisi işsizlik olarak karşımıza çıkmaktadır. Bireylerin işsizliği ülke ekonomileri için ciddi bir sorun olmakla birlikte, iş dünyasının ana aktörleri konumunda olan farklı sektörlerdeki işletmeler de gereksinimlerine karşılık verebilecek, aranan niteliklere sahip işgörenler bulunması konusunda sorunlar yaşamaktadır. Kısaca ifade etmek gerekirse, işsiz birey çok olmakla birlikte, işletmelerin gereksinimlerine yanıt verecek niteliklere sahip işgören adayları maalesef kıttır. Diğer işgören adaylarından farklı nitelikleri ile ayrılan, potansiyelli olduğuna inanılan, kendisinden yüksek performans beklenen, işletmelere rekabette avantaj sağlamayı vaadeden ve işletmelerin kendilerinden büyük beklentileri olan bu işgörenlerin cezbedilmesi, işe alınması, geliştirilmesi ve elde tutulması günümüz iş dünyası için önde gelen insan kaynakları yönetimi konuları arasında sayılmaktadır. Bu bağlamda, yetenekli işgören olarak adlandırılan bu bireylerin cezbedilerek işletmeye kazandırılması, geliştirilmesi ve elde tutulmasına yönelik faaliyetler işletmelerde yetenek yönetimi uygulamaları kapsamında gerçekleştirilebilmektedir.

Farklı yetenek yönetimi uygulamaları sayesinde işletmeler gereksinimlerine yanıt verecek yetenekli işgörenleri cezbedebilecek, onların gelişimlerini sağlayarak daha verimli ve motivasyonu yüksek biçimde çalışmalarına olanak sağlayabilecek ve uzun dönemli olarak işletmede kalmalarının yolunu açabilecektir. Yetenekli işgörenlerin rekabette fark yaratan önemli bir unsur haline gelmesi ve bu işgörenlerin birden fazla işletme tarafından farklı teşviklerle cezbedilmeye çalışılması onların elde tutulmasının zorluğunu göstermektedir. Çalıştığı işletmede beklediği desteği alamayan, gelişimi konusunda gerekli katkı sağlanmayan, iş-yaşam dengesi gözetilmeyen, performanslarına göre farklılaştırılmış bir ücret paketi önerilmeyen, sergiledikleri performans karşısında ödüllendirilmeyen, iddialı iş fırsatları tanınmayan ve farklı kariyer fırsatları sunulmayan yetenekli işgörenler işletmeden ayrılma yönünde bir eğilime girebilirler. İşletmeler gerçekleştirecekleri yetenek yönetimi uygulamaları ile yetenekli işgörenlerinin duygusal bağlılıklarını, iş tatmin düzeylerini ve çalışmaya tutkunluk düzeylerini yükselterek onların elde tutulmasını olanaklı kılmaya çalışırlar. 


\section{H. Boz 13/4 (2021) 3236-3264}

İşletmelerin iyi bir yetenek yönetimi sistemine sahip olmaları, yetenek yönetimi uygulamalarının ve stratejilerinin başarıya ulaşmasında gerekli, ancak yeterli değildir. Yetenekli işgörenlere dönük gerçekleştirilen yetenek yönetimi uygulamalarının işletme içinde kimlerin sorumluluğu altında gerçekleşeceği üzerinde önemle durulan konulardandır. Yetenek yönetimi uygulamalarından istenilen sonuçların elde edilebilmesi başta tepe yönetim olmak üzere, her düzeyde yöneticinin yetenek yönetiminin önemini kavraması ve bu doğrultuda çaba sergilemeleri ile mümkün olmaktadır. Alanyazında da ele alındığı üzere, yetenek yönetimi konusunda tepe yönetimin kararlılığı ve destekleyiciliği, insan kaynakları bölümünün uygulamanın işletme içinde işleyişinin aksamadan yürütülmesi konusundaki çabası ve orta kademe yöneticilerin bizzat uygulayıcısı olarak yetenek yönetimini sahiplenmesi önemli görülmektedir.

Bu çalışmada yetenek yönetimi, işten ayrılma niyeti, duygusal bağlılık, çalışmaya tutkunluk ve iş tatmini değişkenleri bir model üzerinde ele alınmak suretiyle, yetenek yönetimi uygulamalarının yetenekli olarak değerlendirilen işgörenlerin işten ayrılma niyetleri üzerindeki doğrudan ve aracılar yoluyla dolaylı etkileri saptanmaya çalışılmıştır. Çalışma özetle değerlendirilecek olursa, araştırmaya katılan bankacılık sektörü işletmelerinde gerçekleştirilen yetenek yönetimi uygulamalarının işgörenlerin iş tatminleri, çalışmaya tutkunlukları ve duygusal bağlllıkları üzerinde önemli ve anlamlı bir etkiye sahip olduğu açıtır. Yetenek yönetimi uygulamalarının da etkisiyle duygusal bağlllık ve iş tatmini düzeyleri yükselmiş olan işgörenlerin işten ayrılma niyetlerinde anlamlı azalma söz konusudur. Bu bağlamda, uygulamacılar açısından bakıldığında, özellikle 2000'li yıllardan itibaren önemi gittikçe artan yetenek yönetiminin işletmeler tarafından bir felsefe olarak benimsenmesi ve tüm örgüt kademelerinde sistemli biçimde uygulanması yararlı olacaktır. Her işletmenin kendine has bir kültürü ve işleyişi olmasından ötürü, işletmelerin karmaşıklıktan uzak ve kendilerine özgü kültürel yapılarıyla uyumlu yetenek yönetimi sistemlerini kurmalarının yetenek yönetimi konusunda başarıya ulaşmada önemli olduğu söylenebilir. Bu sistem içerisinde sahip oldukları yetenek yönetimi yetkinlikleri ile yöneticilerin önemli bir misyonu vardır. Açıkça ifade edilecek olursa, işgörenlerin performans ve potansiyelleri hakkında en iyi bilgiye sahip olması beklenen kesim bağlı oldukları yöneticilerdir denilebilir. Bu bağlamda, ilgili yöneticilerin yetenek yönetimi uygulamaları konusundaki yetkinlikleri işletmedeki uygulamaların başarıya ulaşmasında önemli bir ölçüt olarak değerlendirilebilir. Kıt olan yetenekli işgörenlerin cezbedilerek işletmeye çekilmesi, geliştirilmesi ve elde tutulması iyi yapılandırılmış yetenek yönetimi sistemleri ve bunu en iyi biçimde hayata geçirebilen yöneticiler sayesinde olanaklı olabilecektir. Araştırma sonuçlarının da gösterdiği üzere, iş tatmini, duygusal bağlllığı ve çalışmaya tutkunluğu yüksek, iş tatmini ve duygusal bağlılığın etkisi ile işten ayrılma niyeti düşük yetenekli işgörenlere sahip olmak için, sektördeki yöneticilerin yetenek yönetimi yetkinlikleri düzeyinin yüksek olması anlamlı olmaktadır.

Araştırmanın sadece Antalya ilinde bulunan yetenek yönetimi uygulayan bankaların şubelerindeki yetenekli işgörenlere yönelik gerçekleştirilebilmiş olması ve sadece yetenekli işgörenlerin algı ve değerlendirmelerinin esas alınmış olması bir kısıt olarak değerlendirilebilir. Bundan dolayı elde edilen sonuçların genellenmesi doğru olmayacaktır. Burada test edilen modelin bankacilık sektörü dışında, yetenek yönetimi uygulamalarının yoğun olduğu başka sektörlerde de (otomotiv, hızlı tüketim malları, ilaç, telekomünikasyon, enerji, vb. gibi) test edilmesi alanyazına anlamlı katkılar sunabilecektir.

Örneklem sayısının yetersizliği dolayısıyla bu çalışmada yöneticilerin yetenek yönetimi yetkinliklerinin her birinin işten ayrılma niyetine etkisini test etmek olanaklı olmamış, yetenek yönetimi yetkinliklerinin genel etkisi test edilebilmiştir. Bu açıdan değerlendirildiğinde, daha geniş örneklem büyüklügü ile çalışılarak her bir yetenek yönetimi yetkinliğinin işten ayrılma niyeti üzerindeki etkisini araştırmak, gerek alanyazın gerekse farklı sektörlerdeki uygulamacılar açısından çok daha anlamlı sonuçların elde edilmesine zemin hazırlayabilecektir. Ayrıca araştırmacılar tarafından, duygusal bağlılık, çalışmaya tutkunluk ve iş tatmini dışında yetenek yönetimi ile işten ayrılma niyeti ilişkisinde aracı ya da düzenleyici etkisi olabilecek olan başka değişkenlerin de (psikolojik sözleşme, işgörenlerin kuşak farklılıkları, vb. gibi) bu modele dâhil edilerek test edilmesi alanyazının gelişmesine yardımcı olacaktır. 


\section{Kaynakça}

Abraham, S. (2012). Job satisfaction as an antecedent to employee engagement, SIES Journal of Management, $8(2), 27-36$.

Agarwal, U. A. ve Gupta, V. (2015). Examining the mediating and moderating effects of engagement and conscientiousness for the job characteristics and intention to quit relationship, Work Paper, Indian Institute Of Management, Ahmedabad, Hindistan.

Ahmad, A. ve Omar, Z. (2010). Perceived family-supportive work culture, affective commitment and turnover intention of employees, Journal of American Science, 6(12), 839-846.

Akbaş, İ. (2013). The relationship between talent management and retention of employees: A case study in banking sector, Yayımlanmamış Yüksek Lisans Tezi, Marmara Üniversitesi Sosyal Bilimler Enstitüsü, İstanbul.

Al Ariss, A., Cascio, W. F. ve Paauwe, J. (2014). Talent management: Current theories and future research directions, Journal of World Business, 49, 173-179.

Alarcon, G. M. ve Lyons, J. B. (2011). The relationship of engagement and job satisfaction in working samples, The Journal of Psychology, 145(5), 463-480.

Alarcon, G. M. ve Edwards, J. M. (2011). The relationship of engagement, job satisfaction and turnover intentions, Stress and Health, 27, 294-298.

Alias, N. E., Noor, N. M. ve Hassan, R. (2014). Examining the mediating effect of employee engagement on the relationship between talent management practices and employee retention in the information and technology (IT) organizations in Malaysia, Journal of Human Resources Management and Labor Studies, 2(2), 227-242.

Aljunaibi, M. M. (2014). Talent management and employee engagement, Yayımlanmamış Yüksek Lisans Tezi, The British University, Dubai.

Allen, N. J. ve Meyer, J. P. (1990). The measurement and antecedents of affective, continuance and normative commitment to the organisation, Journal of Occupational Psychology, 63, 1-18.

Almutairi, D. O. (2016). The mediating effects of organizational commitment on the relationship between transformational leadership style and job performance, International Journal of Business and Management, 11(1), 231-241.

Altınöz, M. (2009). Yetenek Yönetimi. Nobel Yayın Dağıtım, Ankara.

Altunoğlu, A. E., Atay, H. ve Terlemez, B. (2015). İnsan kaynakları bakış açısından yetenek yönetimi: Bankacılık sektörü uygulama örneği, Marmara Üniversitesi İ.I.B. Dergisi, 37(1), 47-70.

Anafarta, N. (2015). Algılanan örgütsel destek ve işten ayrılma niyeti ilişkisi: İş tatmininin aracılık rolü, İ.Ü. İşletme Fakültesi İ̧̧letme İktisadı Enstitüsü Yönetim Dergisi, 26(79), 112-130.

Arı, G. S., Bal, H. ve Bal, E. Ç. (2010). İşe bağlılığın tükenmişlik ve işe bağlanma niyeti ilişkisindeki aracılık etkisi: Yatırım uzmanları üzerine bir araştırma, Süleyman Demirel Üniversitesi İktisadi ve İdari Bilimler Fakültesi Dergisi, 15(3), 143-166.

Arnold, H. J. ve Feldman, D. C. (1982). A multivariate analysis of the determinants of job turnover, Journal of Applied Psychology, 67(3), 350-360.

Aşan, Ö. ve Özyer, K. (2008). Duygusal bağlılık ile iş tatmini ve iş tatmininin alt boyutları arasındaki ilişkileri analiz etmeye yönelik ampirik bir çalışma, Süleyman Demirel Üniversitesi İktisadi ve İdari Bilimler Fakültesi Dergisi, 13(3), 129-151.

Atlı, D. (2012). İnsan Kaynakları Yönetiminin Yeni Vizyonu: Yetenek Yönetimi. Crea Yayıncılık, İstanbul.

Axelrod, B., Handfield-Jones, H. ve Michaels, E. (2002). A new game plan for C players, Harvard Business Review, 80(1), 80-88.

Bakker, A. B., Schaufeli, W. B., Leiter, M. P. ve Taris, T. W. (2008). Work engagement: An emerging concept in occupational health psychology, Work \& Stress, 22(3), 187-200.

Bal, E. A. (2008). Self-efficacy, contextual factors and well-being: the impact of work engagement, Yayımlanmamış Doktora Tezi, Marmara Üniversitesi Sosyal Bilimler Enstitüsü, İstanbul.

Barkhuizen, N., Mogwere, P. ve Schutte, N. (2014). Talent management, work engagement and service quality orientation of support staff in a higher education institution, Mediterranean Journal of Social Sciences, 5(4), 69-77.

Barkhuizen, N., Diseko, E. ve Schutte, N. (2015). The relationship between talent management and turnover intentions of teachers in botswana, 20th International Academic Conference, Madrid, 38-48. 


\section{H. Boz 13/4 (2021) 3236-3264}

Baron R. M. ve Kenny, D.A. (1986). The moderator-mediator variable distinction in social psychological research: Conceptual, strategic, and statistical considerations, Journal of Personality and Social Psychology, 51(6), 1173-1182.

Baş, T. (2002). Öğretim üyelerinin iş tatmin profillerinin belirlenmesi, Dokuz Eylül Üniversitesi İ.İ.B.F. Dergisi, 17(2), 19-37.

Bone, P. F., Sharma, S. ve Shimp, T.A. (1989). A bootstrap procedure for evaluating goodness-of-fit indices of structural equation and confirmatory factor models, Journal of Marketing Research, 26(1), 105-111.

Büyüköztürk, Ş. (2007). Sosyal Bilimler için Veri Analizi El Kitabı, Pegem A Yayıncılık, Ankara.

Camelo-Ordaz, C., García-Cruz, J., Sousa-Ginel, E. ve Valle-Cabrera, R. (2011). The influence of human resource management on knowledge sharing and innovation in Spain: The mediating role of affective commitment, The International Journal of Human Resource Management, 22(7), 1442-1463.

Cappelli, P. ve Keller, J. R. (2014). Talent management: Conceptual approaches and practical challenges, The Annual Review of Organizational Psychology and Organizational Behavior, 1, 305-331.

Ceylan, N. (2007). İnsan kaynakları yönetiminde yetenek yönetimi ve bir uygulama, Yayımlanmamış Yüksek Lisans Tezi, İstanbul Üniversitesi Sosyal Bilimler Enstitüsü, İstanbul.

Chami-Malaeb, R. ve Garavan, T. (2013). Talent and leadership development practices as drivers of intention to stay in lebanese organisations: The mediating role of affective commitment, The International Journal of Human Resource Management, 24(21), 4046-4062.

Cheese, P., Thomas, R. J. ve Craig, E. (2008). The Talent Powered Organization: Strategies for Globalization, Talent Management and High Performance. Kogan Page Limited, Londra, İngiltere.

CIPD. (2007). Talent Management: Research Insight. Chartered Institute of Personnel and Development, Londra, İngiltere.

Cohn, M. J., Khurana, R. ve Reeves, L. (2005). İşiniz ona bağlıymış gibi yetenek geliştirmek. (Çev. İ. Gülfidan). Harvard Business Review Dergisinden Seçmeler: Yetenek Yönetimi. MESS Yayıncıllk, İstanbul, 51-70.

Collings, D. G. ve Mellahi, K. (2009). Strategic talent management: A review and research agenda, Human Resource Management Review, 19, 304-313.

Collings, D. G., McDonnell, A. ve Scullion, H. (2009). Global talent management: The law of the few, Poznan University of Economics Review, 9(2), 5-18.

Crow, M. S., Lee, C-B. ve Joo, J-J. (2012). Organizational justice and organizational commitment among South Korean police officers, Policing: An International Journal of Police Strategies \& Management, 35(2), 402 423.

Currivan, D. B. (1999). The causal order of job satisfaction and organisational commitment in models of employee turnover, Human Resources Management Review, 9(4), 495-524.

Çakar, N. D. ve Ceylan, A. (2005). İş motivasyonunun çalışan bağlılı̆̆ 1 ve işten ayrılma eğilimi üzerindeki etkileri, Doğuş Üniversitesi Dergisi, 6(1), 52-66.

Çarıkçı, İ. H. ve Çelikkol, Ö. (2009). İş-aile çatışmasının örgütsel bağlllık ve işten ayrılma niyetine etkisi, Süleyman Demirel Üniversitesi Sosyal Bilimler Enstitüsü Dergisi, 9, 153-170.

Çekmecelioğlu, H. G. (2005). Örgüt ikliminin iş tatmini ve işten ayrılma niyeti üzerindeki etkisi: bir araştırma, C.Ü. İktisadi ve İdari Bilimler Dergisi, 6(2), 23-39.

Çırpan, H. ve Şen, A. (2009). İşletmelerde yenilikçiliği geliştirmede etkili bir araç: Yetenek yönetimi, Çerçeve Dergisi, 110-116.

Darvish, H., Najafi, Z. ve Zare, R. (2012). Evaluate the level of talent management competencies and its relationship with intention to quit the organization, Journal of Basic and Applied Scientific Research, 2(10), 10068-10076.

Demircioğlu, H. Ö. (2010). Organizasyonlarda yetenek yönetimi ve finans sektöründe bir uygulama, Yayımlanmamış Yüksek Lisans Tezi, Kocaeli Üniversitesi Sosyal Bilimler Enstitüsü, Kocaeli.

Dormann, C. ve Zapf, D. (2001). Job satisfaction: A meta-analysis of stabilities, Journal of Organizational Behavior, 22(5), 483-504.

Dries, N. ve Pepermans, R. (2012). How to identify leadership potential: Development and testing of a consensus model, Human Resource Management, 51(3), 361-385.

Du Plessis, L., Barkhuizen, N., Stanz, K. ve Schutte, N. (2015). The management side of talent: Causal implications for the retention of generation Y employees, The Journal of Applied Business Research, 31(5), 1767-1780. 
Economist Intelligence Unit. (2006). The CEO's Role in Talent Management: How Top Executives from Ten Countries are Nurturing the Leaders of Tomorrow. The Economist, Londra, İngiltere.

Elangovan, A. R. (2001). Causal ordering of stress, satisfaction and commitment, and intention to quit: A structural equations analysis, Leadership and Organisation Development Journal, 22(4), 159-165.

El Badawy, T. A. ve Bassiouny, M. (2014). Employee engagement as a mediator between transformational leadership and intention to quit, $C F, 12(1), 152-160$.

Eren, E. (1996). Yönetim Psikolojisi. Beta Basım Yayım Dağıtım A.Ş., İstanbul.

Fornell, C. ve Larcker, D. F. (1981). Evaluating structural equation models with unobservable variables and measurement error, Journal of Marketing Research, 18(1), 39-50.

Gaylard, M., Sutherland, M. ve Viedge, C. (2005). The factors perceived to influence the retention of information technology workers, South African Journal of Business Management, 36(3), 87-97.

Gegez, A. E. (2007). Pazarlama Araştırmaları. Beta Yayınevi, İstanbul.

Greenberg, J. ve Baron, R. A. (2000). Behavior in Organizations. Prentice-Hall, ABD.

Griffeth, R. W., Hom, P. W. ve Gaertner, S. (2000). A meta-analysis of antecedents and correlates of employee turnover: Update, moderator tests, and research implications for the next millennium, Journal of Management, 26(3), 463-488.

Gussenhoven, E. (2009). Talent management: From an individual perspective. The effect of the amount of talent management practices on affective organizational commitment, with a mediating role of psychological fulfilment, Yayımlanmamış Yüksek Lisans Tezi, Tilburg Üniversitesi, Tilburg.

Gürbüz, S. (2010). Algılanan kurumsal imajın yöneticilerin bazı tutum ve davranışlarına etkisi, Selçuk Üniversitesi Sosyal Bilimler Enstitüsü Dergisi, 24, 229-240.

Gürbüz, S. ve Şahin F. (2015). Sosyal Bilimlerde Araştırma Yöntemleri: Felsefe-Yöntem-Analiz. Seçkin Yayıncılık, Ankara.

Hair, J. F., Anderson, R. E., Tatham, R. L. ve Black, W. C. (1998). Multivariate Data Analysis, Pearson Education, New Jersey.

Hamidi, N., Saberi, H. ve Safari, M. (2014). The effect of implementation of talent management on job satisfaction governmental organizations (Case Study: Ministry of Roads and Urban), Journal of Novel Applied Sciences, 3(1), 100-113.

Hoogervorst, A. M. (2009). How to retain talent? The impact of the amount of talent management practices on turnover intention and the mediating role of psychological contract fulfilment, Yayımlanmamış Yüksek Lisans Tezi, Tilburg Üniversitesi, Naaldwijk.

Hughes, J. C. ve Rog, E. (2008). Talent management, International Journal of Contemporary Hospitality Management, 20(7), 743-757.

Jaros, S. J., Jermier, J. M., Koehler, J. W. ve Sincich, T. (1993). Effects of continuance, affective and moral commitment on the withdrawal process: An evaluation of eight structural equation models, Academy of Management Journal, 36(5), 951-995.

Kalaycı, Ş. (ed.). (2010). SPSS Uygulamah Çok Değişkenli İstatistik Teknikleri. Asil Yayın Dağıtım, Ankara.

Kamil, B. A. M., Hamid, Z. A., Hashim, J. ve Omar, A. (2011). A study on the implementation of talent management practices at Malaysian companies, Asian Journal Of Business And Management Sciences, $1(4), 147-162$.

Kanap Güngör, M. (2013). Bilgi çağında insan kaynakları yönetimine bakış: işletmelerde yetenek yönetimi ve çalışan performansına etkisi üzerine bir araştırma, Yayımlanmamış Yüksek Lisans Tezi, Haliç Üniversitesi Sosyal Bilimler Enstitüsü, İstanbul.

Karabıyık, F. B. (2015). Türk bankacılık sektöründe insan kaynakları yaklaşımı çerçevesinde yetenek yönetimi, Yayımlanmamış Yüksek Lisans Tezi, Muğla Sıtkı Koçman Üniversitesi Sosyal Bilimler Enstitüsü, Muğla.

Kaya, N. ve Selçuk, S. (2007). Bireysel başarı güdüsü organizasyonel bağlllığı nasıl etkiler?, Doğuş Üniversitesi Dergisi, 8(2), 175-190.

Kevük, S. (2006). Bilgi ekonomisi, Journal of Yasar University, 1(4), 319-350.

Khah, G. S., Nezhad, Z. E. ve Moradi, M. (2014). The analysis of the relationship between employees' perceptions talent management and job engagement: The mediating effect of loyalty and job satisfaction, Journal of Social Issues \& Humanities, 2(11), 49-55. 


\section{H. Boz 13/4 (2021) 3236-3264}

Koyuncu, M., Burke, R. J. ve Fiskenbaum, L. (2006). Work engagement among women managers and professionals in a turkish bank: Potential antecedents and consequences, Equal Opportunities International, 25(4), 299-310.

Lewis, R. E. ve Heckman, R. J. (2006). Talent management: A critical review, Human Resource Management Review, 16, 139-154.

Luna-Arocas, R. ve Morley, M. J. (2015). Talent management, talent mindset competency and job performance: The mediating role of job satisfaction, European Journal of International Management, 9(1), 28-51.

Meydan, C. H. ve Şeşen, H. (2011). Yapısal Eşitlik Modellemesi AMOS Uygulamaları. Detay Yayıncılık, Ankara.

Meyer, J. P. ve Allen, N. J. (1997). Commitment in the Workplace. Theory, Research and Application. Sage Publications, Kanada.

Meyer, J. P. ve Herscovitch, L. (2001), Commitment in the workplace: Toward a general model, Human Resource Management Review, 11, 299-326.

Meyer, J. P., Stanley, D. J., Herscovitch, L. ve Topolnytsky, L. (2002). Affective, continuance, and normative commitment to the organization: A meta-analysis of antecedents, correlates, and consequences, Journal of Vocational Behavior, 61, 20-52.

Michaels, E., Handfield-Jones, H., Axelrod, B. (2001). The War For Talent. Harvard Business Review Press, Boston, Massachusetts, ABD.

Mir, A., Mir, R. ve Mosca, J. B. (2002). The new age employee: An exploration of changing employeeorganization relations, Public Personel Management, 31(2), 187-200.

Mitchell, T. R., Holtom, B. C., Lee, T.W., Sablynski, C. J. ve Erez, M. (2001). Why people stay: Using job embeddedness to predict voluntary turnover, The Academy of Management Journal, 44(6), 1102-1121.

Mor Barak, M. E., Nissly, J. A. ve Levin, A. (2001). Antecedents to retention and turnover among child welfare, social work, and other human service employees: What can we learn from past research? A review and metanalysis, Social Service Review, 625-661.

Muslu, İ. (2013). Yetenek yönetimi ve bankacıllk sektöründe bir alan araştırması: Sivas ili örneği, Yayımlanmamış Yüksek Lisans Tezi, Cumhuriyet Üniversitesi Sosyal Bilimler Enstitüsü, Sivas.

Oehley, A-M. (2007). The development and evaluation of a partial talent management competency model, Yayımlanmamış Yüksek Lisans Tezi, Stellenbosch Üniversitesi.

Oshagbemi, T. (1999). Overall job satisfaction: How good are single versus multiple-item measures?, Journal of Managerial Psychology, 14(5), 388-403.

Öner, E. (2014). Bankacıllk sektöründe yetenek yönetimi ve ilişkilendirildiği insan kaynakları fonksiyonları: Bir uygulama, Yayımlanmamış Yüksek Lisans Tezi, Bahçeşehir Üniversitesi Sosyal Bilimler Enstitüsü, İstanbul.

Pepe, M. (2007). The strategic importance of talent management at the Yale New Heaven Health System: Key factors and challenges of TM implementation, Organization Development Journal, 25(2), 207-241.

Peters, T. (2006). Leaders as talent fanatics, Leadership Excellence, 23(11), 12-13.

Ping, T. S. (2011). Impact of talent management practices towards organizational commitment, Yayımlanmamış Yüksek Lisans Tezi, University Sains Malaysia, Malezya.

Poyraz, K. ve Kama, B. (2008). Algılanan iş güvencesinin, iş tatmini, örgütsel bağlllık ve işten ayrılma niyeti üzerindeki etkilerinin incelenmesi, Süleyman Demirel Üniversitesi İktisadi ve İdari Bilimler Fakültesi Dergisi, 13(2), 143-164.

Roberts, D. R. ve O'Davenport, T. O. (2002). Job engagement: Why it's important and how to improve it, Employment Relations Today, 29(3), 21-29.

Rosser, V. J. (2004). Faculty members' intentions to leave: A national study on their worklife and satisfaction, Research in Higher Education, 45(3), 285-309.

Rusbult, C. E., Farrell, D., Rogers, G. ve Mainous III, A. G. (1988). Impact of exchange variables on exit, voice, loyalty, and neglect: An integrative model of responses to declining job satisfaction, The Academy of Management Journal, 31(3), 599-627.

Saks, A. M. (2006). Antecedents and consequences of employee engagement, Journal of Managerial Psychology, 21(7), 600-619.

Schaufeli, W. B., Salanova, M., Gonzalez-Roma, V. ve Bakker, A. B. (2002). The measurement of engagement and burnout: A two sample confirmatory factor analytic approach, Journal of Happiness Studies, 3, 7192. 
Schaufeli, W. B. ve Bakker, A. B. (2004). "Job demands, job resources, and their relationship with burnout and engagement: A multi-sample study, Journal of Organizational Behavior, 25, 293-315.

Serim Bahadınlı, H. (2013). İşletmelerde yetenek yönetimi uygulamalarının çalışanların iş tatmini ve örgüte bağlllıkları üzerindeki etkisi (ilaç, tekstil ve otomotiv sektörlerinde araştırma), Yayımlanmamış Doktora Tezi, Marmara Üniversitesi Sosyal Bilimler Enstitüsü, İstanbul.

Shore, M. L. ve Martin, H. J. (1989). Job satisfaction and organizational commitment in relation to work performance and turnover intentions, Human Relations, 42(7), 625-638.

Sivanesan, G. (2014). A study of talent management strategies in information technology industry at Bangalore City, International Journal of Business Management \& Research, 4(5), 21-30.

Sökmen, A. ve Mete, E. (2015). bezdirinin iş performansı, iş tatmini ve işten ayrılma niyeti üzerindeki etkisi: Ankara'da bir araştırma, Gazi Üniversitesi İktisadi ve İdari Bilimler Dergisi, 17(3), 271-295.

Sweem S. L. (2009). Leveraging employee engagement through a talent management strategy: Optimizing human capital through human resources and organization development strategy in field study, Yayımlanmamış Doktora Tezi, Benedictine University, ABD.

Tanton, S. N. (2007). Talent management in the role of employee retention: A research report, Yayımlanmamış Yüksek Lisans Tezi, Güney Afrika Üniversitesi, Güney Afrika.

Terlemez, B. (2013). Stratejik insan kaynakları bağlamında organizasyonlarda yetenek yönetimi: bankacılık sektörü uygulama örneği, Yayımlanmamış Yüksek Lisans Tezi, Adnan Menderes Üniversitesi Sosyal Bilimler Enstitüsü, Aydın.

Tett, R. P. ve Meyer, J. P. (1993). Job satisfaction, organisational commitment, turnover intention, and turnover: Path analyses based on meta-analytic findings, Personnel Psychology, 46(2), 259-293.

Towers Watson. (2011). Peryön-Towers Watson Türkiye Yetenek Yönetimi Araştırması. 25. Avrupa İnsan Yönetimi Konferansi.

Turgut, T. (2011). Çalışmaya tutkunluk: İş yükü, esnek çalışma saatleri, yönetici desteği ve iş-aile çatışması ile ilişkileri, Atatürk Üniversitesi İktisadi ve İdari Bilimler Dergisi, 25(3-4), 155-179.

Tutar, H. (2007). Erzurum'da devlet ve özel hastanelerde çalışan sağlık personelinin işlem adaleti, iş tatmini ve duygusal bağlllık durumlarının incelenmesi, Süleyman Demirel Üniversitesi İktisadi ve İdari Bilimler Fakültesi Dergisi, 12(3), 97-120.

Türkiye Bankalar Birliği, www.tbb.org.tr, (erişim tarihi: 03.07.2015).

Yalabik, Y. Z., Popaitoon, P., Chowne, J. A. ve Rayton, B. A. (2013). Work engagement as a mediator between employee attitudes and outcomes, The International Journal of Human Resource Management, 24(14), 2799-2823.

Yasmin, K. ve Marzuki, N. A. (2015). Impact of organizational commitment on intention to quit among psychaitric nurses: Evidence from Pakistan, International Journal of Learning \& Development, 5(4), 89102.

Yılmaz, F. (2009). Küreselleşme sürecinde gelişmekte olan ülkelerde ve Türkiye'de iş sağllğı ve güvenliği, Uluslararası İnsan Bilimleri Dergisi, 6(1), 45-72.

Yiğit, M. K. ve Kaplan, B. (2015). Talent management: An application in banking sector in Turkey, Journal of Management, Marketing and Logistics, 2(4), 284-306.

Wasti, S. A. (2002). Affective and continuance commitment to the organisation: Test of an integrated model in the Turkish context, International Journal of Intercultural Relations, 26(5), 525-550.

Weiss, D. J., Dawis, R. W., England, G. W., Lofquist, L. H. (1967). Manual for the Minnesota satisfaction quesitionnaire, Minnesota Studies in Vocational Rehabilitation.

Wiener, Y. (1982). Commitment in organizations: A normative view, The Academy of Management Review, 7(3), 418-428. 